\title{
Site ${\mathrm{C} 0002^{1}}^{2}$
}

\author{
Expedition 332 Scientists $^{2}$
}

\section{Chapter contents}

Background and objectives.......... 1

Operations...................

Downhole measurements............ 4

Long-term borehole monitoring system . . . . 5

Vortex-induced vibration measurements . . . . 8

Discussion .................... 9

References.................. 10

Figures................... 11

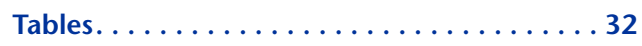

${ }^{1}$ Expedition 332 Scientists, 2011. Site C0002. In Kopf, A., Araki, E., Toczko, S., and the Expedition 332 Scientists, Proc. IODP, 332: Tokyo (Integrated Ocean Drilling Program Management International, Inc.).

doi:10.2204/iodp.proc.332.104.2011

'Expedition 332 Scientists' addresses.

\section{Background and objectives}

Integrated Ocean Drilling Program (IODP) Site C0002 is slated for deep drilling across the entire plate boundary system, including the megasplay fault at $\sim 5000$ meters below seafloor (mbsf) and the décollement at $\sim 7000$ mbsf, planned during later stage riser drilling (Tobin and Kinoshita, 2006). The overall scientific objective for the Nankai Trough Seismogenic Zone Experiment (NanTroSEIZE) observatory is to understand interseismic behavior of the seismogenic zone fault system through in situ monitoring of seismic, geodetic, and hydrological properties.

Site C0002 is located in the southern part of the Kumano Basin (Fig. F1). The Kumano Basin has a generally flat topography at $\sim 2000 \mathrm{~m}$ water depth. The sediments in the southern part of the Kumano Basin are tilted northward, truncated by a flat erosional surface, and subsequently cut by normal faults (Park et al., 2002; Moore et al., 2007) (Fig. F2).

This site is situated above the uppermost part of a seismogenic fault of the Tonankai earthquakes, which occurred during an interval 100-150 y from the recorded history of the earthquakes. The seismogenic plate boundary is at $\sim 7000$ mbsf, whereas another splay fault propagating with a larger dip angle to the surface is at $\sim 5000$ mbsf. Further south (i.e., seaward), the plate boundary is considered aseismic, but the occurrence of very low frequency earthquakes was reported based on observations by a seismic network on land such as Hi-net.

To date, six holes have been drilled at Site C0002, all within $100 \mathrm{~m}$ of each other (Fig. F3). Site C0002 was first explored in 2007 during IODP Expedition 314 (Kinoshita et al., 2008), with a full suite of logging while drilling (LWD)/measurement while drilling (MWD) to 1401 mbsf (Hole C0002A; Expedition 314 Scientists, 2009). These measurements revealed the structure, physical properties, and stress state of the Kumano forearc basin, the gas hydratebearing zone, and the underlying deformed rocks of the inner accretionary prism (Fig. F4). A prominent bottom-simulating reflector (BSR) interpreted as the base gas hydrate reflection is evident at $\sim 400 \mathrm{mbsf}$ in the log resistivity, gamma ray, $P$-wave velocity, and density data.

Borehole breakouts indicate northeast-southwest oriented maximum horizontal compression throughout the whole interval, perpendicular to that at IODP Sites C0001 (thrust sheet of megasplay thrust) and C0009 (Kumano forearc basin) (Fig. F4). Fracture and 
fault orientations also support margin-normal extension of this part of the forearc. This extension is probably driven by uplift of the megasplay/outerarc high causing gravitationally driven extension of the inner wedge (Expedition 314 Scientists, 2009). This contrasts with Site C0001 in the active prism (outer wedge), where convergence-related compression dominates.

During IODP Expedition 315, Holes C0002B, C0002C, and C0002D were drilled. Core samples were taken from 0 to 204 mbsf and 475 to 1057 mbsf (Expedition 315 Scientists, 2009). Based on LWD and core data, the lithology is classified into four units. Unit I (0-135.8 m core depth below seafloor [CSF]) contains sand and silt intercalation and has a fast sedimentation rate. The age of the unit ranges from Quaternary to late Miocene. The forearc basin sequence was divided into two units based on lithofacies; these units corresponded to Units II (135.8-830.4 m CSF) and III (830.4-921.7 m CSF), defined by LWD. Both units are dominated by mud and mudstone. Although core recovery was poor (35\% on average for the bottom interval cored with the rotary core barrel [RCB]), the basal unconformity of the Kumano forearc basin was encountered at $922 \mathrm{~m} \mathrm{CSF}$, or $936 \mathrm{~m} \mathrm{LWD}$ depth below seafloor (LSF), and another $120 \mathrm{~m}$ was cored into the accretionary prism. The underlying accretionary prism materials contain more lithified and deformed sediments. Acoustic features in Unit IV (921.7 m CSF and below), characterized by irregular discontinuous horizons, suggest that it may be composed of chaotically deformed accretionary wedge sedimentary mélange transported from significantly greater depths.

Faults and shear zones are clustered around 700, 920-950, and 1000-1050 m CSF. Three deformation phases were recognized by fault analyses. The earliest phase is a thrust fault (and possibly a strike-slip fault) and exhibits northwest-southeast shortening. Two phases of normal faulting occurred subsequent to thrusting. The first is recorded in shear zones and indicates northeast-southwest extension. The second is recorded in normal faults and indicates northsouth extension, consistent with the present stress direction acquired from LWD results. A total of 31 whole-round samples were taken for interstitial water analyses. Changes in concentration for most elements seem to be controlled by unit boundaries. A downhole increase of ethane and concomitant decrease of $\mathrm{C}_{1} / \mathrm{C}_{2}$ ratios in Unit IV suggest some contribution of thermogenic hydrocarbon gas. Downhole temperature was measured at eight depths to $159.0 \mathrm{~m} \mathrm{CSF}$ and showed an almost linear downhole increase with a gradient of $0.043^{\circ} \mathrm{C} / \mathrm{m}$.

IODP Expedition 326 (NanTroSEIZE Stage 3: plate boundary deep riser: top hole engineering) was the first of several project stages that will ultimately drill and core to the boundary between the Philippine Sea and Eurasian plates, the ultimate target of the NanTroSEIZE complex drilling project (Kinoshita et al., 2010). Expedition 332 ran from 19 July to 20 August 2010. Hole C0002F (Fig. F3) was drilled to $868.5 \mathrm{mbsf}$, and the hole was cased with 20 inch casing. A corrosion cap was set in preparation for future planned drilling.

The primary objective at Site C0002 during Expedition 332 was to install a permanent borehole observatory in the basal forearc basin (Unit III) dominated by condensed mudstone and the upper accretionary prism with interbeds of mudstone, siltstone, and sandstone (Unit IV) (Fig. F5). This long-term borehole monitoring system (LTBMS) will ultimately be connected to a submarine cable network for monitoring earthquakes and tsunamis, the Dense Oceanfloor Network System for Earthquakes and Tsunamis (DONET).

\section{Operations}

The D/V Chikyu moved toward Site C0002 after midnight on 12 November 2010, moving upstream of the site to prepare the 20 inch casing and jetting-in the bottom-hole assembly (BHA) with the mudmat and wellhead assembly connected (Table T1). At $1830 \mathrm{~h}$ on 13 November, the BHA was run into the water $15 \mathrm{nmi}$ upstream of Site C0002. The remotely operated vehicle (ROV) dove at about the same time, and the BHA was run into the water, with $40 \mathrm{~m}$ of the 20 inch casing hanging below, until it reached $1441 \mathrm{~m}$ drilling depth below rig floor (DRF), whereupon anti-vortex-induced vibration (VIV) ropes were attached to the upper portion of the drill pipe as it continued being run. By $0330 \mathrm{~h}$ on 14 November, the BHA reached $1861 \mathrm{~m}$ DRF while the Chikyu continued to drift to Site C0002. The Chikyu reached $2.5 \mathrm{nmi}$ from Site C0002 by $0600 \mathrm{~h}$ on 15 November while the ROV continued monitoring the BHA and running tool for signs of VIV. At $1247 \mathrm{~h}$ the BHA position was confirmed by ROV and the ship's dynamic positioning (DP) systems, and the seafloor was tagged at $1256 \mathrm{~h}$. Hole C0002G was at $33^{\circ} 18.0126^{\prime} \mathrm{N}$, $136^{\circ} 1488^{\prime} \mathrm{E}$ in water depth of $1966 \mathrm{~m}$ DRF (1937.5 m mud depth below sea level). Jetting in with the 20 inch casing began at $1307 \mathrm{~h}$. The cart was released by the ROV at $1630 \mathrm{~h}$, and beginning at $1700 \mathrm{~h}$ the running tool was picked up to $1970 \mathrm{~m}$ DRF while ropes were removed from the drill string.

The BHA was pulled out of the hole to the surface and was laid down at $0330 \mathrm{~h}$ on 16 November. Once recovered, there was a short stop at $0710 \mathrm{~h}$ as the Chikyu moved to a low-current area (LCA) to rendezvous 
with the Heisei maru to backload the circulation obviation retrofit kit (CORK) running tool for transport ashore. At $1230 \mathrm{~h}$ the guide horn was moved to the moonpool for assembly and was completed by $1815 \mathrm{~h}$, after which the $12^{1 / 4}$ inch drilling LWD/MWD BHA was made up and run into the hole at $1900 \mathrm{~h}$. By $0618 \mathrm{~h}$ on 17 November, the BHA had reached $1787 \mathrm{~m} \mathrm{DRF}$ as the Chikyu drifted along with the current, reentering the wellhead at $0945 \mathrm{~h}$. Reaming to the bottom of the 20 inch casing at $2007 \mathrm{~m}$ DRF began, and drilling with LWD to $2267 \mathrm{~m}$ DRF commenced at $1030 \mathrm{~h}$. Drilling reached $2573 \mathrm{~m}$ DRF at $1145 \mathrm{~h}$ on 18 November when a short trip to the casing shoe to circulate and clean the hole was run from 1230 to $1430 \mathrm{~h}$. The run back to the bottom resumed at $1630 \mathrm{~h}$, and drilling resumed from 2573 to $2675 \mathrm{~m}$ DRF at $1830 \mathrm{~h}$. The BHA reached $2858 \mathrm{~m}$ DRF, an initial 95/8 inch casing shoe target depth, at $1045 \mathrm{~h}$ on 19 November when cleaning and sweeping of the hole was resumed.

The BHA was pulled out of the hole to $1810 \mathrm{~m}$ DRF with no overpull and then resumed pulling out of the hole to the rig floor. The ROV was recovered at $1640 \mathrm{~h}$ as the Chikyu drifted along the current and continued to pull the BHA out of the hole. The LWD/MWD BHA was laid down at $0100 \mathrm{~h}$ on 20 November, and 105/8 inch BHA was made up and run into the hole at $0130 \mathrm{~h}$. At $0800 \mathrm{~h}, 1 \mathrm{nmi}$ from Hole C0002G, the ROV dove and the BHA run into the hole was paused, resuming at $1030 \mathrm{~h}$, and the BHA reentered the hole at $1130 \mathrm{~h}$. By $1145 \mathrm{~h}$ the BHA was at $2785 \mathrm{~m}$ DRF, where a short relogging trip began from 2785 to $2804 \mathrm{~m} \mathrm{DRF}$ and again from 2830 to $2858 \mathrm{~m} \mathrm{DRF}$, first to overlap the proposed casing shoe depth and also to confirm the suitability of the proposed strainmeter depth and sensor carrier positioning. At $1900 \mathrm{~h}$, drilling with the 105/8 inch BHA LWD assembly began from $2858 \mathrm{~m}$ DRF to total depth (TD) (2946 m DRF), which was reached at $0230 \mathrm{~h}$ on 21 November when circulation to clean the hole began, sweeping with $10 \mathrm{~m}^{3}$ of $\mathrm{Hi}-\mathrm{Vis}$ mud. After sweeping was completed at $0445 \mathrm{~h}$, the BHA was pulled out of the hole to $2862 \mathrm{~m}$ DRF to relog from 2859 to $2830 \mathrm{~m}$ DRF because the live-streaming LWD data were missing two resistivity channels and did not appear in play back after TD was reached. Relogging finished at $0600 \mathrm{~h}$, after which the BHA made a short trip to $2500 \mathrm{~m}$ DRF.

The BHA was run down to the bottom at $0715 \mathrm{~h}$ for circulation. There was some concern about hole conditions deteriorating below $2934 \mathrm{~m} \mathrm{DRF}$, as the BHA began experiencing pack off. Circulation began at $0900 \mathrm{~h}$, and a wiper trip to the 20 inch casing shoe was completed at $1200 \mathrm{~h}$. A run back to the bottom, starting at $1500 \mathrm{~h}$, showed no more trouble with hole conditions, as reaming slowly to $2945 \mathrm{~m}$ DRF had no problems. Hi-Vis mud was spotted at $1900 \mathrm{~h}$, pulling out of the hole to $1870 \mathrm{~m}$ DRF began at $2015 \mathrm{~h}$, and the BHA was clear of the wellhead at $2330 \mathrm{~h}$. By $0615 \mathrm{~h}$ on 22 November, the $105 / 8$ inch BHA was laid down, and then the $95 / 8$ inch casing was readied to be run in the hole while moving to the LCA. At $0845 \mathrm{~h}$ the guide horn was rigged down, and at $1130 \mathrm{~h}$ the casing was rigged up and ready to run. At $1330 \mathrm{~h}$ the casing was run in, reaching $130 \mathrm{~m}$ DRF by $1730 \mathrm{~h}$. The casing screen joints were run in the hole from 1330 to $1945 \mathrm{~h}$, followed by the rest of the casing, while the Chikyu began drifting back to Hole C0002G.

Anti-VIV ropes were deployed on the drill pipe from $1360 \mathrm{~m}$ DRF at $0600 \mathrm{~h}$ on 23 November until $1830 \mathrm{~m}$ DRF was reached at $2000 \mathrm{~h}$ that evening. Once the ropes were securely tied off (terminated) on the drill string, the guide horn was reinstalled and completed by $2300 \mathrm{~h}$. From that point, drifting back to reenter Hole C0002G continued all day on 24 November, reaching $1.5 \mathrm{nmi}$ from the location at $2300 \mathrm{~h}$, whereupon the ROV dove. No VIV was observed throughout the entire time the drill string was hung while drifting back to Hole C0002G.

The casing BHA reached $10 \mathrm{~m}$ above the wellhead at $0300 \mathrm{~h}$ on 25 November, and the ROV stood by to observe reentry into the wellhead. The casing was run into the wellhead, reaching the planned setting depth (2853 m DRF) by $0530 \mathrm{~h}$. Cementing the casing began at $0930 \mathrm{~h}$ on 25 November, after which the casing hanger tool was released and pulled out of the hole while the drill string was cleared. The ROV was recovered on deck by $1330 \mathrm{~h}$, and the casing hanger was recovered on deck by $0200 \mathrm{~h}$ on 26 November. The cement stand and head were examined, and the wiper plug was found trapped above the drop indicator inside the cement head. The Chikyu began moving to Shimizu, Japan, for port call, arriving by $0700 \mathrm{~h}$ on 27 November.

The Chikyu stayed quayside, loading and unloading tools and equipment, leaving port at $2000 \mathrm{~h}$ and making way back to Site C0002. The Chikyu reached $7 \mathrm{nmi}$ upstream of Site C0002 at $1730 \mathrm{~h}$ on 28 November, went into DP mode, and installed the ROV cursor rail at $2030 \mathrm{~h}$. The drill out cement BHA was run into the hole to $1860 \mathrm{~m}$ DRF by $0130 \mathrm{~h}$ on 29 November while drifting back toward Hole C0002G.

The ROV dove at $0315 \mathrm{~h}$ on 29 November, and at $0830 \mathrm{~h}$ the BHA was run into the hole to $2826 \mathrm{~m}$ DRF to begin drilling out cement. After a short trip to the $95 / 8$ inch float shoe, the BHA was run to $2943 \mathrm{~m}$ DRF, the hole was swept, and high-density brine and protect zone were spotted into the hole at $1530 \mathrm{~h}$. After spotting, the BHA was pulled out of the hole from the wellhead at $1715 \mathrm{~h}$, and then the Chikyu drifted as the drill pipe continued to be recovered. 
Taking position $20 \mathrm{nmi}$ northwest of Site C0002, the CORK running tool was picked up and makeup began at $0500 \mathrm{~h}$ on 30 November. The upper guide horn was rigged down at $0730 \mathrm{~h}$, and the completion assembly was prepared for running into the hole. Running into the hole began at $2300 \mathrm{~h}$ on 30 November, with stopping for connection and termination of three cables, the flatpack, and the thermistor string on the sensor carrier instruments at $0700 \mathrm{~h}$ on 1 December. Joints of $3 \frac{1}{2}$ inch tubing were run with four centralizers per joint up to the swellable packer at $1400 \mathrm{~h}$ on 2 December. The electrical cables, flatpack, and hydraulic lines were run through the packer body seal by $1630 \mathrm{~h}$ on 2 December, after which the electrical cables were tested at $2215 \mathrm{~h}$ to ensure that the connections to the sensors were still viable after working them through the packer.

Running continued from $2300 \mathrm{~h}$ on 2 December to $948 \mathrm{~m}$ DRF on 3 December, when the CORK head was readied for attachment to the completion assembly. The CORK running tool was picked up and mated to the CORK head by $0045 \mathrm{~h}$ on 4 December and run through the rotary table by $0200 \mathrm{~h}$. The electrical cables were again tested at $0400 \mathrm{~h}$, after which the cables were measured for cutting and termination. Termination by Ocean Design, Inc. (ODI) engineers began at $0730 \mathrm{~h}$ on 4 December, and the terminated cables were installed on the CORK head at $0830 \mathrm{~h}$ on 5 December. The ROV platform was lowered to the moonpool in preparation for assembly and attachment to the CORK head at $1645 \mathrm{~h}$. Stands of drill pipe were fixed to the CORK running tool and run into the hole to $1300 \mathrm{~m}$ DRF by $2230 \mathrm{~h}$ on 5 December while the ROV entered the water. The completion assembly was run to $1417 \mathrm{~m} \mathrm{DRF}$, where the ROV tested the underwater mateable connectors (UMCs) on the CORK head at $0200 \mathrm{~h}$ on 6 December. All connections passed inspection, and the completion assembly continued being run into the hole to $1897 \mathrm{~m}$ DRF by $0045 \mathrm{~h}$ on 8 December. The UMCs were successfully checked again by ROV at $0430 \mathrm{~h}$ on 8 December before running the CORK assembly into the wellhead.

The Chikyu approached and shifted position before running the CORK completion assembly into the wellhead at $0845 \mathrm{~h}$. The assembly was run to $2904 \mathrm{~m}$ DRF, and the CORK head was landed on the wellhead at $2015 \mathrm{~h}$ on 8 December. One more systems check was performed on the tiltmeter and strainmeter UMCs only because the broadband seismometer connector was in danger of being damaged by the ROV arm. All checks were successfully completed by $2200 \mathrm{~h}$. Cementing was finished by 0230 h on 9 December, and the unjay stopper and CORK running tool were released at $0330 \mathrm{~h}$. The running tool was pulled out of the hole to the surface by $1355 \mathrm{~h}$ on 9 December.

\section{Downhole measurements}

\section{Logging-while-drilling results}

Gamma ray and attenuation/phase shift resistivity measurements were made using the LWD arcVISION825 tool described in "Downhole measurements" in the "Methods" chapter (Expedition 332 Scientists, 2011b). The four units described here and identified by changes in frequency, amplitude, or magnitude of the data are believed to reflect changes in lithology. Suspected boundaries were compared with data from Expedition 314 to confirm that the signature and depth of the transition was consistent with logging results from Hole C0002A:

1. The Unit I/II boundary was reached at 129 mbsf, marked by a notable, consistent increase in both gamma ray and resistivity.

2. The Unit II/III boundary was identified at 827 mbsf, directly below distinct negative gamma ray and resistivity peaks. Gamma ray values do not show any significant change in amplitude of oscillations, in contrast to phase shift resistivity, which is characterized by a sudden quiescence or amplitude reduction after passing the boundary (Fig. F6).

3. The Unit III/IV boundary was identified at 931 mbsf. The transition is clearly visible through the sudden decrease in gamma ray and attenuation resistivity data at the boundary. Moreover, both data sets show strong oscillations downhole, indicating a highly heterogeneous material.

In addition to these boundaries, two smaller zones were identified in Unit II: Zone A from 215.5 to 399 mbsf and Zone B from 481.5 to 546.5 mbsf. Zone A shows no significant variations in gamma radiation but steadily increases below the Unit I/II boundary. Attenuation resistivity, however, decreases for a short interval, after which both resistivity measurements show strong variations and distinct peaks with very high values. Below Zone A at 399 mbsf, the strong variations suddenly disappear, synchronous with a sharp drop in overall resistivity and gamma ray. Resistivity continues to exhibit lower values with less variation until the transition to Zone $\mathrm{B}$ (481.5 mbsf) is reached, where gamma ray drops again significantly and resistivity values become highly variable. Throughout Zone A, both resistivity measurements and gamma ray are characterized by higher amplitude oscillations (relative to Zone B), beginning at 481.5 mbsf until 546.5 mbsf.

The main objective for the upper interval (i.e., Unit II) of LWD was to identify an appropriate zone for hydrologic monitoring of ambient pore pressure and transience. To this end, a relatively continuous zone of estimated low permeability (i.e., clay- or mudstone) 
was required, as identified by a zone of elevated resistivity and gamma ray measurements. Based on these criteria, four adequate locations for the third pressure port (PP3) of the LTBMS were identified: (1) 424-473 mbsf, (2) 549-574 mbsf, (3) 614-649 mbsf, or (4) 759-784 mbsf. Interval iv was chosen because it enabled the most favorable configuration of the instrument package. The final location of pressure Port PP3 was $\sim 760$ mbsf.

For measuring hydrostatic reference pressure, pressure Port PP4 was situated at the wellhead, whereas pressure Port PP2 was installed within the cemented region directly below the strainmeter at $\sim 917 \mathrm{mbsf}$. There, it is to be used as a proxy for strain or confirm successful cementing of the strainmeter. Pressure Port PP1 was situated below the cement port at 947 mbsf, with the primary objective of monitoring ambient and transient pore pressure within the accretionary prism.

\section{Correlation with Hole C0002A}

LWD/MWD measurements were conducted in Hole C0002A during Expedition 314 (Kinoshita, Tobin, Ashi, Kimura, Lallemant, Screaton, Curewitz, Masago, Moe, and the Expedition 314/315/316 Scientists, 2009), and here these data are compared to the new downhole measurements from Hole C0002G. Hole C0002A is located $50 \mathrm{~m}$ east-northeast of Hole C0002G, in the same (Kumano) basin, and it was anticipated that the same lithologic units would be encountered at similar depths. The Expedition 314 scientists identified four lithologic units from LWD measurements: Quaternary upper forearc unit (Unit I), lower forearc unit (Unit II), basal forearc unit (Unit III), and the accretionary prism (Unit IV) (for details, see Kinoshita, Tobin, Ashi, Kimura, Lallemant, Screaton, Curewitz, Masago, Moe, and the Expedition $314 / 315 / 316$ Scientists, 2009). The definition of these units was based on a more comprehensive suite of LWD measurements, which included gamma ray, resistivity, bulk density, porosity, etc. The transitions between these units (gamma ray and resistivity) show the same signatures but more pronounced than were described for Hole C0002G (Fig. F7). Moreover, the boundaries are situated at similar depths: the Unit I/II boundary is at $135.5 \mathrm{mbsf}(6.5 \mathrm{~m}$ deeper), the Unit II/III boundary is at $830.4 \mathrm{mbsf}$ (3.4 $\mathrm{m}$ deeper), and the Unit III/IV boundary is at 935.6 mbsf (4.6 m deeper).

The division of smaller zones within Unit II is, with the exception of Zone A, similar to our interpretation, as well as the general character of the gamma ray and resistivity data that helped to define the zones (Kinoshita, Tobin, Ashi, Kimura, Lallemant, Screaton, Curewitz, Masago, Moe, and the Expedition
314/315/316 Scientists, 2009). Consistent with the unit boundaries, the transitions of the different zones are also shifted. Zone A was defined as a slightly thinner section from 218.1 to $400.4 \mathrm{mbsf}$, whereas Zone $\mathrm{B}$ is slightly thicker, ranging from 481.6 to 547.1 mbsf. These boundaries also correlate well with geologic features identified in the 3-D seismic data set (Moore et al., 2007). The sudden decrease in both resistivity measurements in Holes C0002G and C0002A, for example, corresponds with the appearance of a reflector simulating the seafloor but showing a reversed polarity, which cuts the other seismic reflectors, usually referred to as the BSR (Fig. F8).

Because of the similarity in LWD logs, the nearly identical position of the boundaries, and the small distance between the boreholes, a reasonable conclusion is that the units identified in Hole C0002G are the same units defined in Hole C0002A.

The absolute differences in depth between the LWD/ MWD measurements from Holes C0002A and C0002G are only minor. At $\sim 6 \mathrm{~m}$ difference, the first boundary shows the largest difference, which is probably related to the normal faulting observed in the Quaternary forearc unit of the Kumano Basin. The $4.6 \mathrm{~m}$ difference of the Unit III/IV boundary is probably related to folding of the accretionary prism and the lowermost part of Unit III. Therefore, it seems that despite deformation and faulting that are abundant in the upper accretionary prism, their effect on the location of the boundaries is negligible within such a short distance. Also, the boundaries are not significantly affected by the depositional history of the Kumano Basin because the turbiditic sequences appear fairly homogeneous.

\section{Long-term borehole monitoring system}

All completion operations for the long-term observatory installation at Site C0002 were conducted during IODP Expedition 332, beginning with drilling the hole with LWD and followed by installation of $9 \%$ inch casing with a screened section. We then prepared a completion string with all the sensors, cables, pressure ports, and hydraulic lines, a swellable packer (attached to $3 \frac{1}{2}$ inch tubing joints), and finally terminated the assembly with a CORK head mounting UMCs and hydraulic lines with valves and a pressure recorder (Fig. F9). The final assembly operation involved attaching the ROV platform to the string prior to lowering everything into the water. All of the string assembly was conducted in a LCA to reduce the chance of damage and interference with safe operations from the Kuroshio Current to the sensitive instruments and cables. The following comprised the 
most difficult operations for observatory installation at Site C0002: drifting and guiding the whole completion string into the borehole location without damage from the 3.5-4.5 kt Kuroshio Current in the uppermost 500 meters below sea level (mbsl). Suppression of current-induced vibration was successful (see "Vortex-induced vibration measurements"). Also, a series of communication tests with the individual borehole instruments were conducted to confirm the health of sensors and cables in the course of operations such as lowering, drifting, reentering the borehole, and landing before cementing of the instrument. A detailed sequence of operations is given in "Operations." Here, we describe how the borehole and completion string were configured and assembled, including tests conducted to verify each step of observatory installation as well as the initial data obtained from the borehole.

\section{Completion string}

The main part of the completion string was the $3 \frac{1}{2}$ inch tubing, functioning as a central support for the observatory and as a cement delivery line for cementing the strainmeter and seismic instruments. The tubing supports the cables and hydraulic lines (flatpack with triple $1 / 4$ inch stainless steel tube) as well as the thermistor string in the lower $146 \mathrm{~m}$ section above the instrument carrier. Because the cables and the thermistor string are delicate and susceptible to damage from being scratched on the casing or open borehole, the cables were secured to the tubing with tie wraps spaced at intervals of $\sim 1 \mathrm{~m}$ (Fig. F10). We also attached finned centralizers (Fig. F11) to the tubing to help prevent damage to the cables from brushing the casing and borehole wall. In the lower section, we inserted four centralizers per tubing joint, and two centralizers per tubing joint above the float collar depth. At each centralizer, the cables were covered with rubber protectors. Hydraulic tubes were attached to the tubing with stainless bands as illustrated in Figure F10.

Because there is a small clearance between the outside diameter of the $3 \frac{1 / 2}{2}$ inch tubing and the drift diameter of the $95 / 8$ inch casing ( $~ 8.6$ inches or so), extra care was needed to prevent unintentionally increasing the diameter of the string after fastening the cables and wrapping with tie wraps, tape, and rubber protectors. In critical sections, such as just above the instrument carrier and at the CORK head landing point to the casing hanger, we also checked the clearance to the borehole using a ruler (Fig. F11).

The swellable packer is another point of small clearance to the $95 / 8$ inch casing. Swelling began as soon as the packer was attached to our system and lowered into the sea. We checked the swelling of the packer by ROV camera before running the string into the borehole (Fig. F12). The packer is designed to swell and seal the inside diameter of the $95 / 8$ inch casing within 2 weeks after installation, although the sealing time may be extended by cold water temperatures. Visual inspection of the swellable packer using the ROV confirmed measurable inflation after 4 days of installation. We did not encounter difficulties inserting the packer into the casing to the intended depth.

The orientation of the seismic and tilt sensors relative to each other is constrained by the design of the instrument carrier, and we tried to orient the sensors to face east by rotating the whole completion string during visual inspection by ROV before the string was entered into the borehole.

\section{Layout of sensors}

The location of the strainmeter, tiltmeter, seismometers, and pressure ports for pore fluid pressure monitoring were determined based on information obtained from a nearby borehole (Hole C0002A 50 m eastnortheast of Hole $\mathrm{C} 0002 \mathrm{G}$ ) drilled during a previous expedition as well as LWD data collected during the drilling of Hole C0002G for observatory installation. Gamma ray and resistivity data from LWD tools in Hole C0002G showed good correlation with the Expedition 314 Hole C0002A LWD data set, confirming the depths of major boundaries, with only a few meters difference in depth (see "Downhole measurements").

The bottom-hole pressure port (PP1, Fig. F13) is configured to sit below the Unit III/IV boundary to sample pore fluid pressure in the accretionary complex beneath the Kumano Basin sediment. The depth of the strainmeter location was chosen carefully to position its sensing surface $(1.7 \mathrm{~m}$ interval) into the zone without fracture in the lower Unit III mudstone layer. Pressure Port PP2 then occupies a depth just below the strainmeter sensing surface (Fig. F14). The strainmeter depth is further considered so that the other seismic instruments, connected just above the strainmeter, may also be situated in a fracture free zone. Above the strainmeter is the instrument carrier (Fig. F15), hosting a Guralp broadband seismometer and tilt combo package (tiltmeter, geophone, accelerometer, and thermometer string digitizer). Depths of each of the five thermometer nodes of the thermistor string were determined automatically from the depth of the instrument carrier where the bottom of the thermistor string is terminated at the digitizer. We tried to optimize the location of the thermometer node by cutting and molding the thermistor string after LWD drilling of Hole C0002G, which resulted in a total thermistor string length of $146 \mathrm{~m}$, with the two uppermost nodes positioned in the 
screened casing interval, one below in the casing (but not cemented), and the remaining two nodes in the cemented section above the instrument carrier.

The 95/8 inch casing string represents important equipment used to guide all sensors to the bottom open hole section safely, but the casing shoe needed to be located above the seismic sensor and cemented section to ensure that no casing motion from above is transmitted to the seismic sensors. In this hole, the casing shoe depth was set at 888 mbsf, above the top of instrument carrier, in an interval where there were no significant washouts. The depth of the screened casing was set in a mudstone layer in Unit II so that we can compare the pore fluid pressure in sedimentary layers with the accretionary prism. Finally, the swellable packer depth was chosen to be close to the screened casing interval to minimize the volume associated with the pressure measurement in pressure Port PP3, yet in accordance with 95/8 inch casing configuration so that the packer sealing surface $(\sim 1.5 \mathrm{~m})$ does not overlap with the casing joint. Table T2 and Figure F9 summarize the depth of major observatory items along with unit boundaries in Hole C0002G.

Cementing is another crucial part of the observatory. The strainmeter needs to be coupled to the formation in order to sense the change of ground strain. Fluid flow around the strainmeter and seismic sensors causes severe noise. Therefore, the strainmeter and seismic sensors mounted in the instrument carrier were cemented in the open hole section below the $95 / 8$ inch casing shoe to provide good coupling, eliminate free fluids in the vicinity of seismic sensors, minimize sensing volume (i.e., fluids) around the bottom pressure Port PP1, and provide isolation from the motion of the $95 / 8$ inch casing. Schlumberger "FlexSTONE" cement slurry with nonshrinking characteristics was used to cement the strainmeter and seismic instrument. The slurry was optimized and tested in a laboratory to give a Young's modulus similar to that of the target formation to be as compatible as possible to the surrounding formation in the zone of strainmeter installation, resulting in a Young's modulus of $5.5 \mathrm{GPa}$, Poisson's ratio of 0.17 , and specific gravity of $1.90 \mathrm{~g} / \mathrm{cm}^{3}$.

\section{Assembly and tests during installation}

Prior to the assembly of the completion string, each sensor went through a series of testing. The strainmeter was tested in a pool in the Japan Agency for Marine-Earth Science and Technology (JAMSTEC) for background noise performance before shipment to Shimizu. It was also tested and set up for deployment in the Core-tech shop on the Chikyu before being made up with $3 \frac{1}{2}$ inch tubing on the rig floor. The tilt combo system and Guralp CMG3T seismometer were tested for function and performance in the Matsushiro vault before shipment to the Chikyu (see "Long-term borehole monitoring system" in the "Methods" chapter [Expedition 332 Scientists, 2011b]). These instruments also went through overnight test runs on the Chikyu and were setup for deployment in the Core laboratory and assembled onto the instrument carrier in the Core-tech shop. The software in the strainmeter and tilt combo was organized to go through an automated checking procedure upon power up so that a change in the condition of the instrument may be identified by comparison with previous test results.

While building up the instruments with tubing joints and cables to form the completion string, we performed a function check of these three instruments at each major step where the condition of the instruments could have been affected:

1. Upon connection to the borehole cable,

2. Before inserting the cable to the swellable packer,

3. After inserting the cable to the swellable packer,

4. Before cutting cable for termination to the ODI connectors,

5. After cable termination,

6. After mounting the terminated connectors on the CORK head,

7. After running the string in water and when the CORK head is at $350 \mathrm{mbsl}$,

8. After drifting and before running the string into the borehole, and

9. When the CORK head landed on to the reentry funnel.

For each of these tests, we performed function checks for the points listed in Table T3. After landing the completion string onto the wellhead, we checked the condition of the strainmeter and tilt combo systems by ROV communication and set the valve positions of the pressure system to prepare for circulation and cementing of the borehole instruments. After cementing, the drill string was released from the completion string at the CORK head. Finally, we initialized the observatory by operating valves to connect the borehole pressure ports to the pressure logger as well as to recover initial borehole pressure data by ROV communication.

These tests produced more or less the same results each time, proving the healthy condition of each instrument, except that one of the strainmeter valve status indicators showed erratic values after the test prior to cable termination. This will have little effect on the function of the instrument and continued installation because the valve indicator is for an optional valve that is usually not used, and we also confirmed that the corresponding valve as well as 
others can be operated without any problem. During Test 8 (after drifting and before running the string into the borehole), the ROV pulled the ODI UMC for the Guralp CMG3T seismometer too hard and separated the connector from the mounting plate, but the cable remained undamaged and there was no problem with the function of the seismometer. We took extra care when connecting to other ODI connectors for the strainmeter and tilt combo because the mounting structure was similar for all three instruments. No similar problems were encountered with the strainmeter and tilt combo and we confirmed that these instruments were functioning normally after landing the whole completion string in the borehole. Still, we decided to postpone another check on all three instruments after cementing until we visit the observatory using the JAMSTEC R/V Kaiyo and ROV Hyper dolphin. Prior to another attempt to download data, it is planned to additionally secure the connectors for safer ROV operation.

\section{Observatory status and initial data recovery}

Before lowering the completion string into the water, all the hydraulic tubes were opened to seawater pressure by opening two-way valves on Bay 1 of the CORK head, allowing fluid to enter the tube and displace trapped air. All of the pressure transducers were connected to ocean by three-way valves to protect the transducer from excess pressures and damage. After landing on the borehole but prior to cementing, all two-way valves were closed to inhibit borehole fluid flow in the hydraulic tubes and were kept closed until after cementing operations. When cementing was completed and the completion string was released using the running tool, we switched the three-way valves to connect three pressure transducers to start observation of borehole pressure. By ROV communication, we obtained a record of $\sim 15 \mathrm{~h}$ since observation started as well as all pressure readings prior to switching the valves that record the pressure of seawater at the depth of the pressure recorder. The record (Fig. F16) clearly shows tidal variations with the pressure disturbance during circulation and cementing before the valves were switched. After switching the valves, we observed a shift in pressure and different tidal response from the ocean, especially for the bottom pressure port (PP1) below the cemented section near the strainmeter. At first glance, this suggests the cement column successfully isolated the bottom section from the upper sections.

We obtained temperature data from bottom-hole instruments and thermometer string as shown in Table T4. These temperature readings were consistent, except that the strainmeter temperature was lower by $2^{\circ} \sim 3^{\circ} \mathrm{C}$. One possible explanation may be that the thermometer is enclosed in the pressure cylinder and we kept lowering the string until just before the measurement was taken. Communication with the Guralp CMG3T seismometer was confirmed before lowering the instrument into the borehole and will be checked during the next visit to the observatory by ROV connection, along with the other instruments.

Before leaving the observatory, we made sure the valve configurations and the ODI connectors for the bottom-hole instruments were protected by a dust cover to prepare for the next visit to initialize the observatory for long-term observation. Figures F17, F18, and F19 illustrate the arrangement of the seafloor part of the observatory (CORK head and ROV platform), showing orientation of the pressure recorder and ODI Teledyne UMCs.

\section{Vortex-induced vibration measurements}

Two accelerometers were affixed to the drill string when the LTBMS sensor assembly was lowered in the LCA ( $<1 \mathrm{kt}$; see Fig. F5 in the "Site C0010" chapter [Expedition 332 Scientists, 2011c]). Accelerometer 1 was attached at $1002 \mathrm{~m}$ DRF (just above the CORK head running tool) at $2030 \mathrm{~h}$ on 5 December 2010 and Accelerometer 2 was attached at $1720 \mathrm{~m}$ DRF at $0732 \mathrm{~h}$ on 6 December. The Chikyu's drifting speed was $\sim 0.5 \mathrm{kt}$ to further reduce VIV, as suggested from VIV measurements collected during the SmartPlug retrieval at IODP Site C0010 (see Fig. F13 in the "Site C0010" chapter [Expedition 332 Scientists, 2011c]). The angle between the Chikyu's drifting direction and sea current was $\sim 45^{\circ}$, and the ship began drifting toward Site C0002 at $0830 \mathrm{~h}$ on 6 December, arriving at $0045 \mathrm{~h}$ on 8 December.

An abundance of acceleration data was collected during LTBMS installation at Site C0002. An example of the full data set collected is shown in Figure F20. The same features of acceleration shocks caused by the drill pipe contacting the rotary table during lowering and pulling up as seen in the results from SmartPlug operations are observed in the acceleration data. Acceleration during reentry was much lower $(0.5 \mathrm{~g}$ peak to peak amplitude) than during SmartPlug retrieval, mostly in vertical and horizontal directions where significant force was applied to latch on. The shocks during ROV operations on the CORK head ROV platform and cementing after lowering the sensor assembly are new observations. They appear to increase in strength because the drill string is "fixed" in the borehole while the ROV applies significant push force to connect to the ODI connectors. The maximum peak to peak amplitude of the acceleration 
was $\sim 6 \mathrm{~g}$. These results show that significant acceleration shocks can occur after successful placement in the wellhead and that further care should be taken to avoid damaging the delicate sensors to help insure the success of the LTBMS installation.

The results during drifting from the LCA to Site C0002 show the amplitude of VIV was successfully reduced to $<0.5 \mathrm{~g}$, especially the amplitude of the vertical component of the acceleration during drifting $(<0.2 \mathrm{~g})$. Similar to operations at Site C0010 (see Fig. F13 in the "Site C0010" chapter [Expedition 332 Scientists, 2011c]), two types of vibrations are also observed in the Site $\mathrm{C0002}$ acceleration data set: one induced by the current and a second caused by the drill string hitting the carts in the moonpool (i.e., spikes extending beyond the background drifting VIVs in Fig. F20 in the yellow shaded region).

\section{Discussion}

In this section, we discuss two aspects of Hole C0002G drilling and observatory results. First, we review the LWD/MWD results of Expedition 332 and compare them to the records of Hole C0002A drilled in 2007 during Expedition 314 (Kinoshita, Tobin, Ashi, Kimura, Lallemant, Screaton, Curewitz, Masago, Moe, and the Expedition 314/315/316 Scientists, 2009). Second, we examine the LTBMS installation procedure in the context of the difficult environmental conditions of the strong Kuroshio Current.

\section{LWD}

As described in "Downhole measurements," the unit boundaries identified during Expedition 332 are a good match for those identified in Hole C0002A during Expedition 314 (Kinoshita, Tobin, Ashi, Kimura, Lallemant, Screaton, Curewitz, Masago, Moe, and the Expedition 314/315/316 Scientists, 2009). The first boundary dividing the Quaternary forearc unit (Unit I) and the underlying lower forearc unit (Unit II) is represented in both LWD and MWD data sets as a sudden, constant trend to higher resistivity values. The transition between the lower forearc unit and the basal forearc unit (Unit III) shows an equally significant decrease in amplitude and frequency in the resistivity log. The lowermost boundary between the basal forearc unit and the accretionary prism (Unit IV) shows the opposite behavior: both gamma ray and resistivity experience a sudden drop, followed by a highly oscillating signal in the accreted mudstones. The absolute differences in depth between the LWD/MWD measurements from Holes C0002A and C0002G are minor, ranging between 3 and $6 \mathrm{~m}$. Despite deformation and faulting in the upper prism and a complex depositional history of the Kumano
Basin being filled by turbiditic sequences, no major material changes or depth variations of the boundaries occur (Kinoshita, Tobin, Ashi, Kimura, Lallemant, Screaton, Curewitz, Masago, Moe, and the Expedition 314/315/316 Scientists, 2009).

\section{Long-term borehole observatory installation}

Given the potential hazard of unfavorable current velocities and resulting VIV along the drill string, precautions were taken to minimize VIV by attaching ropes to the upper portion of the drill string above the CORK head assembly (see Fig. F13 in the "Expedition 332 summary" chapter [Expedition 332 Scientists, 2011a]). This operational measure turned out to be very successful for Site C0002 and kept VIV forces to a minimum, which was confirmed by ROV surveys and observation in the moonpool area as well as accelerometer recordings on the drill string.

In addition, special precautions were taken to secure the subseafloor instrument string and its various components. At short notice, centralizers were ordered and supplied that facilitated the installation of stainless steel bands or, alternatively, plastic tie wraps (see Fig. F26 in the "Methods" chapter [Expedition 332 Scientists, 2011b]). The spacing of the centralizers was $\sim 2 \mathrm{~m}$ below the swellable packer (four units per joint of tubing) and $\sim 4-5 \mathrm{~m}$ above the packer (two units per joint). Between the centralizers, numerous tie wraps and metal bands were carefully attached to hold the three cables, the thermistor string (where present), and the flatpack containing the hydraulic lines in place. Where needed, additional duct tape was attached to avoid slack in the lines running up. Spacing of the bands and wraps could be as close as every $20 \mathrm{~cm}$ in places, particularly in areas where the completion assembly outside diameter increased (i.e., near the instrument carrier, centralizers, packer assembly, etc.). The procedure turned out to be timeconsuming but highly successful, and ROV surveys in the water column confirmed that everything remained in place during the entire deployment. VIV was also kept to a minimum during drifting and landing (see "Vortex-induced vibration measurements"), and the good health of all observatory components was confirmed after having completed Hole C0002G.

ROV operations further helped constrain the various design modifications on the LTBMS compared to earlier CORKs (e.g., Becker and Davis, 2005; Mikada, Becker, Moore, Klaus, et al., 2002). It turned out to be an advantage to have the ODI connector of the pressure unit in a horizontal position, with the sensitive portion of the instrument below shielded by a stainless steel cover. This facilitates and hence shortens 
ROV bottom time because the pilots can fly in with a stretched-out manipulator arm without being overly cautious of damaging something in case they slightly miss the connector on occasion. The vertically aligned ODI connectors proved to be less practical because they cannot be reached by the ROV as effortlessly and also impose the risk of damage because shear forces are applied if the vehicle fails to push or pull in a perfectly vertical direction.

The communication lines can be seen as a major achievement in this LTBMS development in that checks of the instrument's functionality could be carried out at (almost) all times. Given the special adapter and ROV interface unit, plus an additional onboard interface board (Fig. F21), testing was possible with the programmed applications and a portable mini-PC. These tests were first carried out on board the ship in a containerized lab shack and were then transferred to the ROV shack once the CORK head was launched into the water (see details in "Long-term borehole monitoring system"). Such operations are possible on the Chikyu but are also desirable for future installations (e.g., on the $\mathrm{R} / \mathrm{V}$ JOIDES Resolution) because they help minimize the risk of instrument loss or malfunction and optimize operations.

\section{References}

Becker, K., and Davis, E.E., 2005. A review of CORK designs and operations during the Ocean Drilling Program. In Fisher, A.T., Urabe, T., Klaus, A., and the Expedition 301 Scientists, Proc. IODP, 301: College Station, TX (Integrated Ocean Drilling Program Management International, Inc.). doi:10.2204/iodp.proc.301.104.2005

Expedition 314 Scientists, 2009. Expedition 314 Site C0002. In Kinoshita, M., Tobin, H., Ashi, J., Kimura, G., Lallemant, S., Screaton, E.J., Curewitz, D., Masago, H., Moe, K.T., and the Expedition 314/315/316 Scientists, Proc. IODP, 314/315/316: Washington, DC (Integrated Ocean Drilling Program Management International, Inc.). doi:10.2204/iodp.proc.314315316.114.2009

Expedition 315 Scientists, 2009. Expedition 315 Site C0002. In Kinoshita, M., Tobin, H., Ashi, J., Kimura, G., Lallemant, S., Screaton, E.J., Curewitz, D., Masago, H., Moe, K.T., and the Expedition 314/315/316 Scientists, Proc. IODP, 314/315/316: Washington, DC (Integrated Ocean Drilling Program Management International, Inc.). doi:10.2204/iodp.proc.314315316.124.2009

Expedition 332 Scientists, 2011a. Expedition 332 summary. In Kopf, A., Araki, E., Toczko, S., and the Expedition 332 Scientists, Proc. IODP, 332: Tokyo (Integrated Ocean Drilling Program Management International, Inc.). doi:10.2204/iodp.proc.332.101.2011

Expedition 332 Scientists, 2011b. Methods. In Kopf, A., Araki, E., Toczko, S., and the Expedition 332 Scientists, Proc. IODP, 332: Tokyo (Integrated Ocean Drilling Pro- gram Management International, Inc.). doi:10.2204/ iodp.proc.332.102.2011

Expedition 332 Scientists, 2011c. Site C0010. In Kopf, A., Araki, E., Toczko, S., and the Expedition 332 Scientists, Proc. IODP, 332: Tokyo (Integrated Ocean Drilling Program Management International, Inc.). doi:10.2204/ iodp.proc.332.103.2011

Heki, K., 2007. Secular, transient and seasonal crustal movements in Japan from a dense GPS array: implication for plate dynamics in convergent boundaries. In Dixon, T.H., and Moore, J.C. (Eds.), The Seismogenic Zone of Subduction Thrust Faults: New York (Columbia Univ. Press), 512-539.

Kinoshita, M., Tobin, H., Ashi, J., Kimura, G., Lallemant, S., Screaton, E.J., Curewitz, D., Masago, H., Moe, K.T., and the Expedition 314/315/316 Scientists, 2009. Proc. IODP, 314/315/316: Washington, DC (Integrated Ocean Drilling Program Management International, Inc.). doi:10.2204/iodp.proc.314315316.2009

Kinoshita, M., Tobin, H., Eguchi, N., and Nielsen, S., 2010. NanTroSEIZE Stage 3: plate boundary deep riser: top hole engineering. IODP Sci. Prosp., 326. doi:10.2204/ iodp.sp.326.2010

Kinoshita, M., Tobin, H., Moe, K.T., and the Expedition 314 Scientists, 2008. NanTroSEIZE Stage 1A: NanTroSEIZE LWD transect. IODP Prel. Rept., 314. doi:10.2204/ iodp.pr.314.2008

Mikada, H., Becker, K., Moore, J.C., Klaus, A., et al., 2002. Proc. ODP, Init. Repts., 196: College Station, TX (Ocean Drilling Program). doi:10.2973/odp.proc.ir.196.2002

Moore, G.F., Bangs, N.L., Taira, A., Kuramoto, S., Pangborn, E., and Tobin, H.J., 2007. Three-dimensional splay fault geometry and implications for tsunami generation. Science, 318(5853):1128-1131. doi:10.1126/science. 1147195

Moore, G.F., Park, J.-O., Bangs, N.L., Gulick, S.P., Tobin, H.J., Nakamura, Y., Sato, S., Tsuji, T., Yoro, T., Tanaka, H., Uraki, S., Kido, Y., Sanada, Y., Kuramoto, S., and Taira, A., 2009. Structural and seismic stratigraphic framework of the NanTroSEIZE Stage 1 transect. In Kinoshita, M., Tobin, H., Ashi, J., Kimura, G., Lallemant, S., Screaton, E.J., Curewitz, D., Masago, H., Moe, K.T., and the Expedition 314/315/316 Scientists, Proc. IODP, 314/315/316: Washington, DC (Integrated Ocean Drilling Program Management International, Inc.). doi:10.2204/iodp.proc.314315316.102.2009

Park, J.-O., Tsuru, T., Kodaira, S., Cummins, P.R., and Kaneda, Y., 2002. Splay fault branching along the Nankai subduction zone. Science, 297(5584):1157-1160. doi:10.1126/science.1074111

Seno, T., Stein, S., and Gripp, A.E., 1993. A model for the motion of the Philippine Sea plate consistent with NUVEL-1 and geological data. J. Geophys. Res., [Solid Earth], 98(B10):17941-17948. doi:10.1029/93JB00782

Tobin, H.J., and Kinoshita, M., 2006. NanTroSEIZE: the IODP Nankai Trough Seismogenic Zone Experiment. Sci. Drill., 2:23-27. doi:10.2204/iodp.sd.2.06.2006

Publication: 11 December 2011 MS 332-104 
Figure F1. Index map showing location of Site C0002. Green circles = previous NanTroSEIZE sites, red circles = Expedition 332 sites, black box $=$ location of 20063 -D seismic reflection data acquisition, black line $=$ KR0108-5 2-D seismic profile, yellow arrows = estimated far-field vectors between Philippine Sea plate and Japan (Seno et al., 1993; Heki, 2007), stars = epicentral location of great earthquakes. Inset shows location of Nankai Trough around the drill sites.

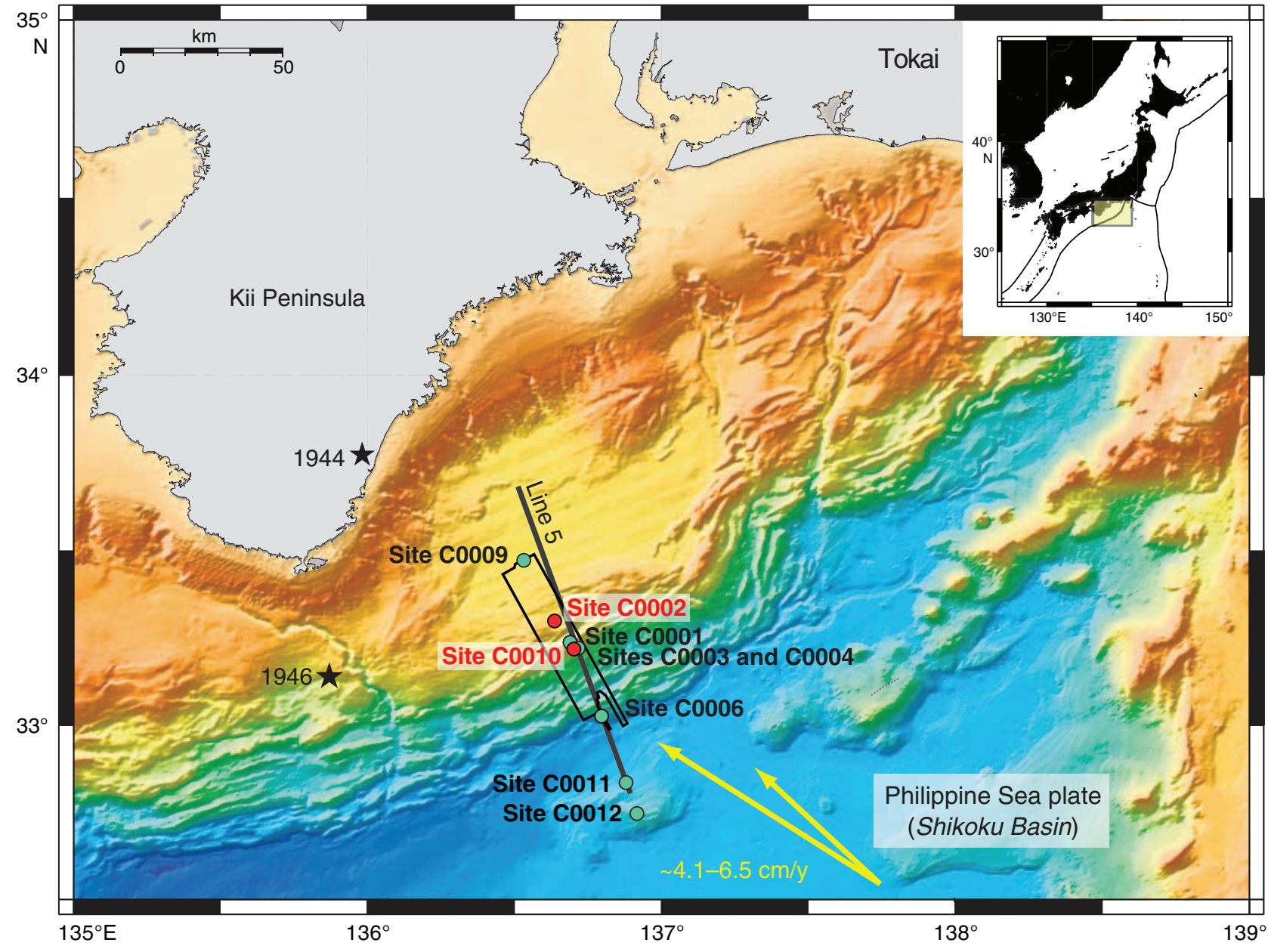


Figure F2. Seismic in-line (IL) crossing Site C0002 (Moore et al., 2009). BSR = bottom-simulating reflector, VE = vertical exaggeration, $\mathrm{XL}=$ cross-line. Red arrows $=$ sedimentary onlap.

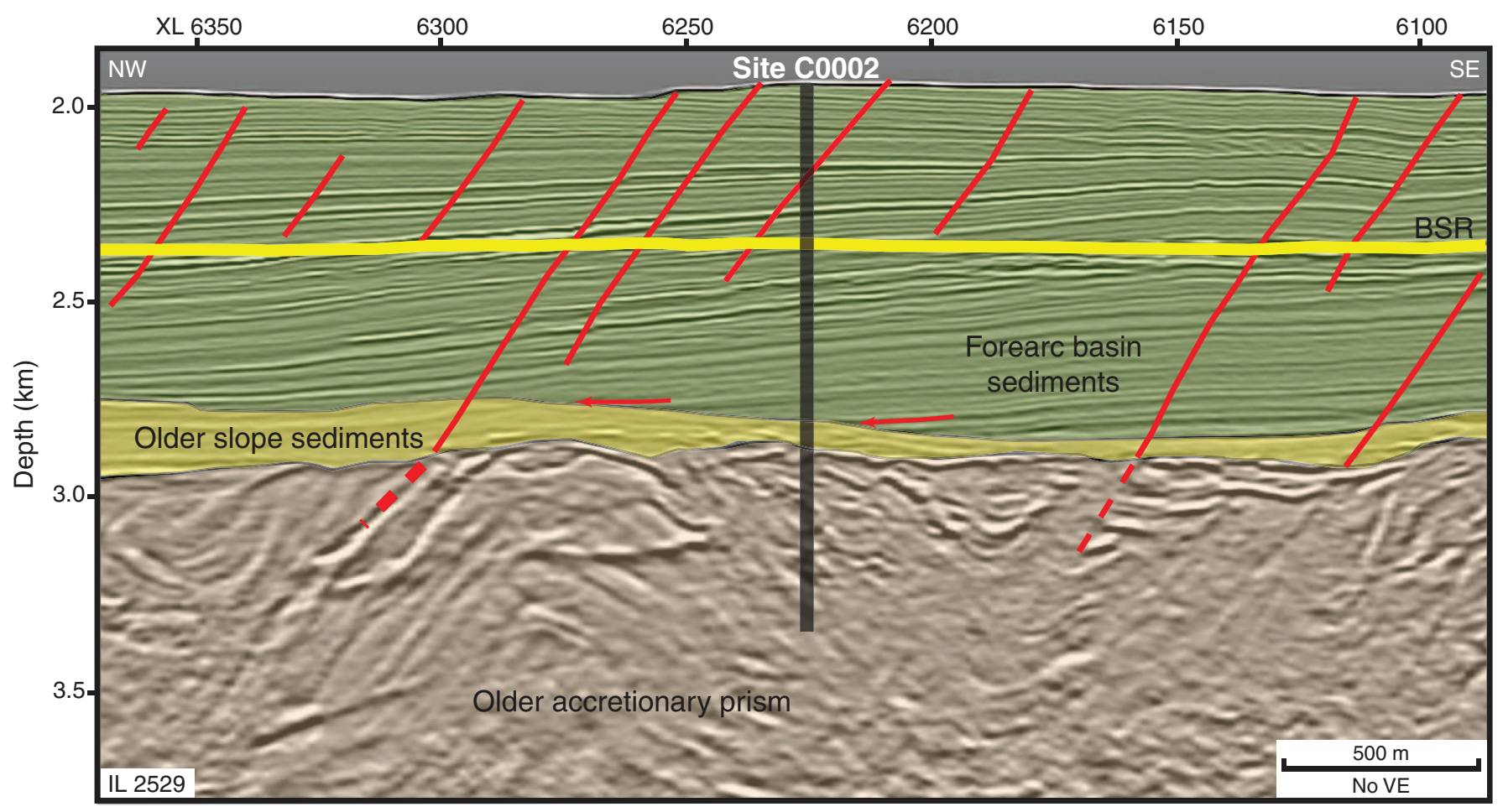


Figure F3. Bathymetric map, Site C0002 (modified after Kinoshita et al., 2010). Black stars = holes drilled during previous NanTroSEIZE expeditions, green circle = Expedition 332 hole.

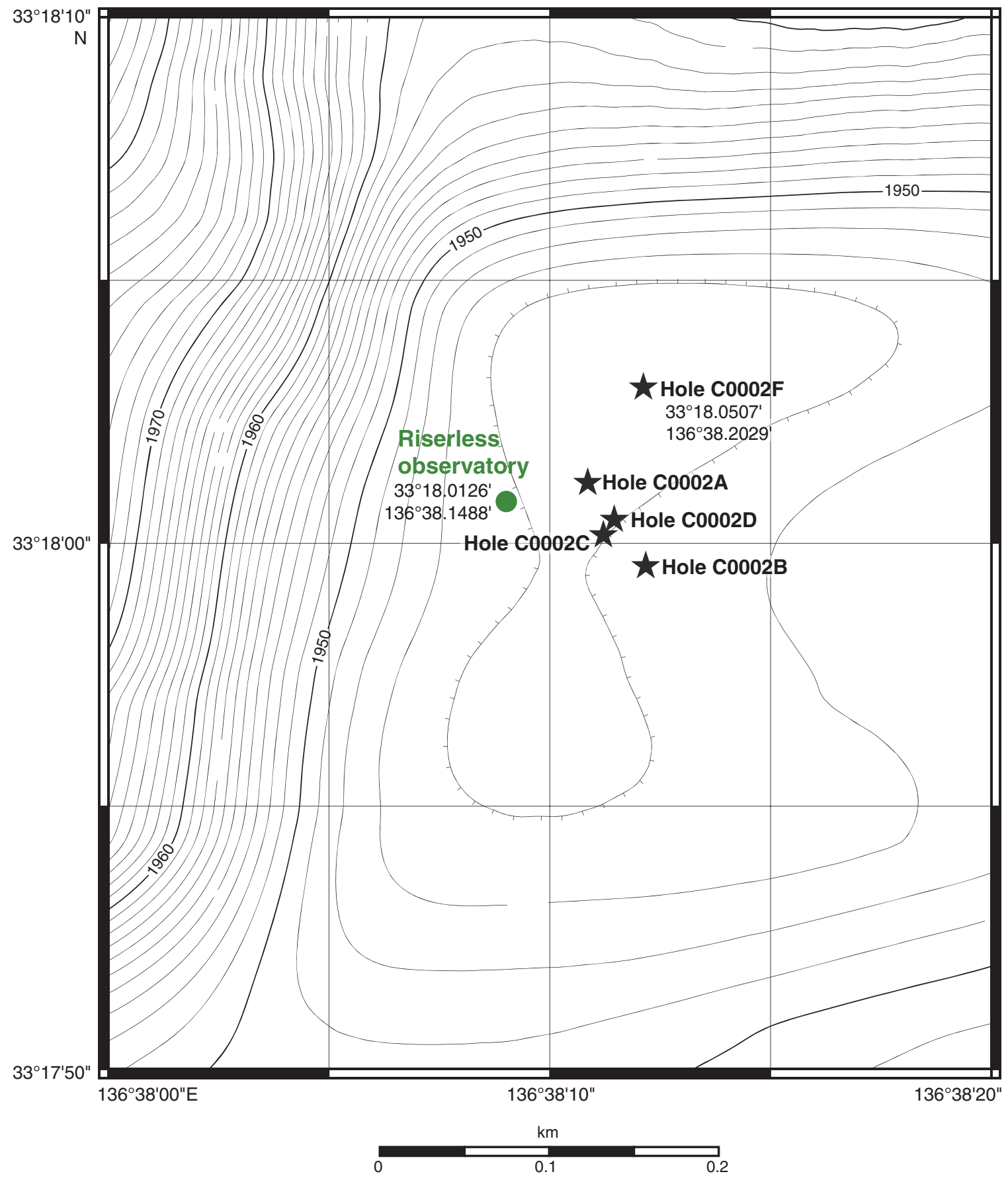


Figure F4. Summary log diagram at Site C0002 obtained during Expedition 314 (Expedition 314 Scientists, 2009). Bedding and fracture dips from resistivity at bit image. $\mathrm{VE}=$ vertical exaggeration, $\mathrm{PEF}=$ photoelectric effect. Black tadpoles $=$ bedding, red tadpoles $=$ fracture, tadpole line $=$ dip direction of plane.

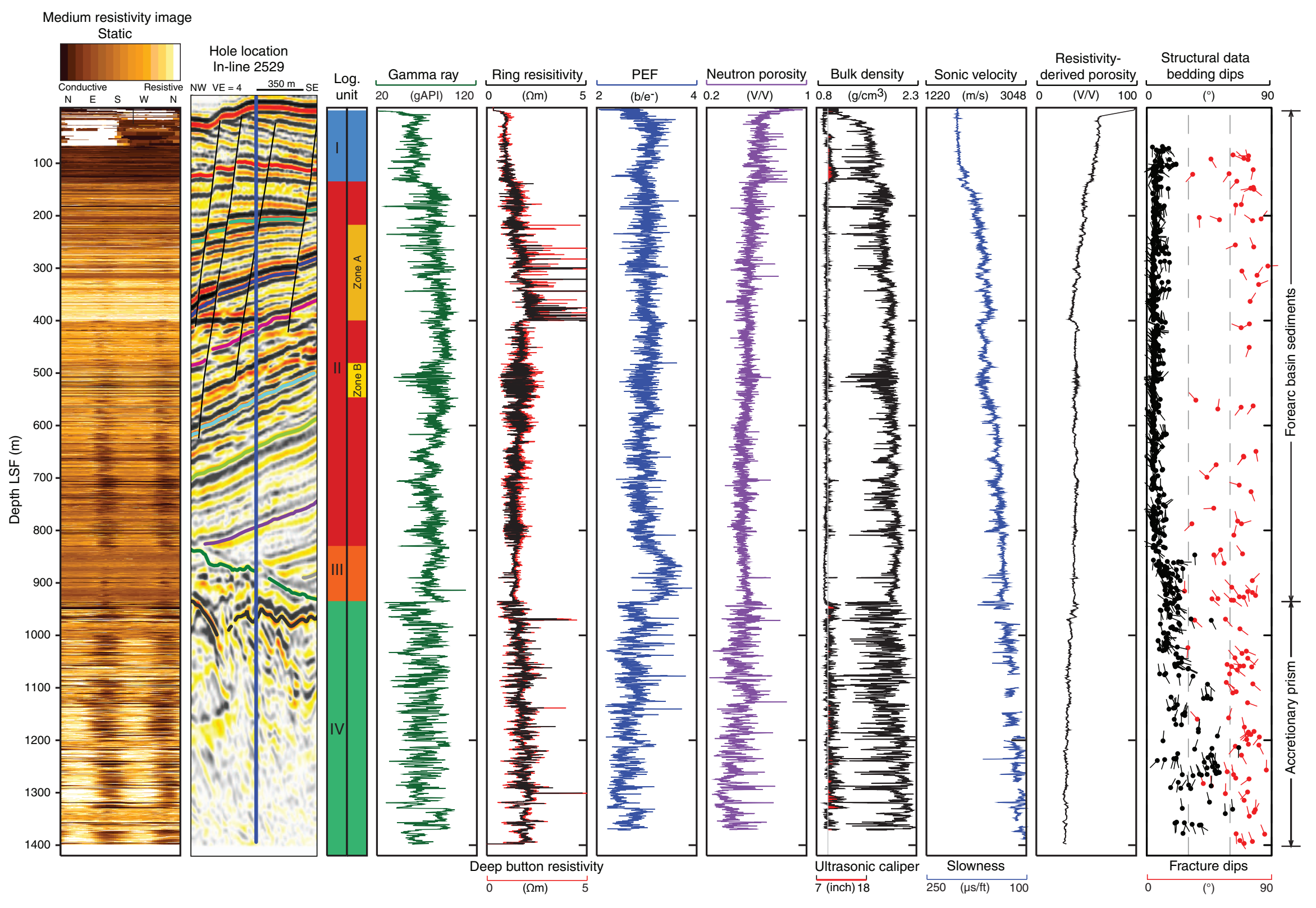


Figure F5. Blowup log data (from Expedition 314) at Site C0002, with layout of borehole instrument of the installed observatory in Hole C0002G.

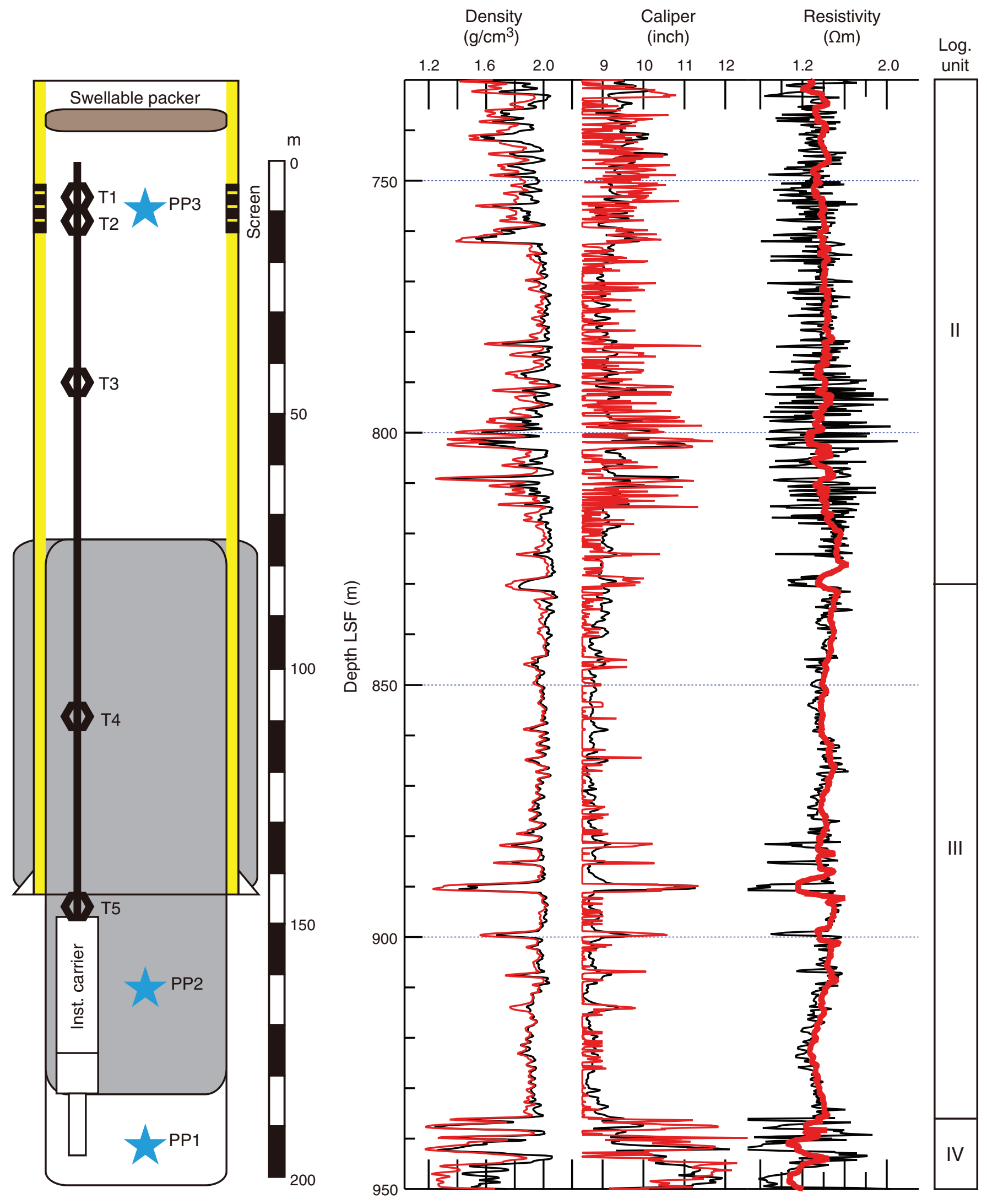


Figure F6. Results of LWD/MWD measurements, Hole C0002G. Two different resistivity measurements were conducted: attenuation and phase shift resistivity, based on amplitude and phase difference, respectively, between the signals registered at the two receivers. Interpretation of the units/zones follows the definition made by Expedition 314 Scientists (Kinoshita, Tobin, Ashi, Kimura, Lallemant, Screaton, Curewitz, Masago, Moe, and the Expedition 314/315/316 Scientists, 2009) for Hole C0002A, which is located 50 m east-northeast of Hole C0002G. TD = total depth.

${ }^{*}=$ position of pressure ports (PP) along the LTBMS.

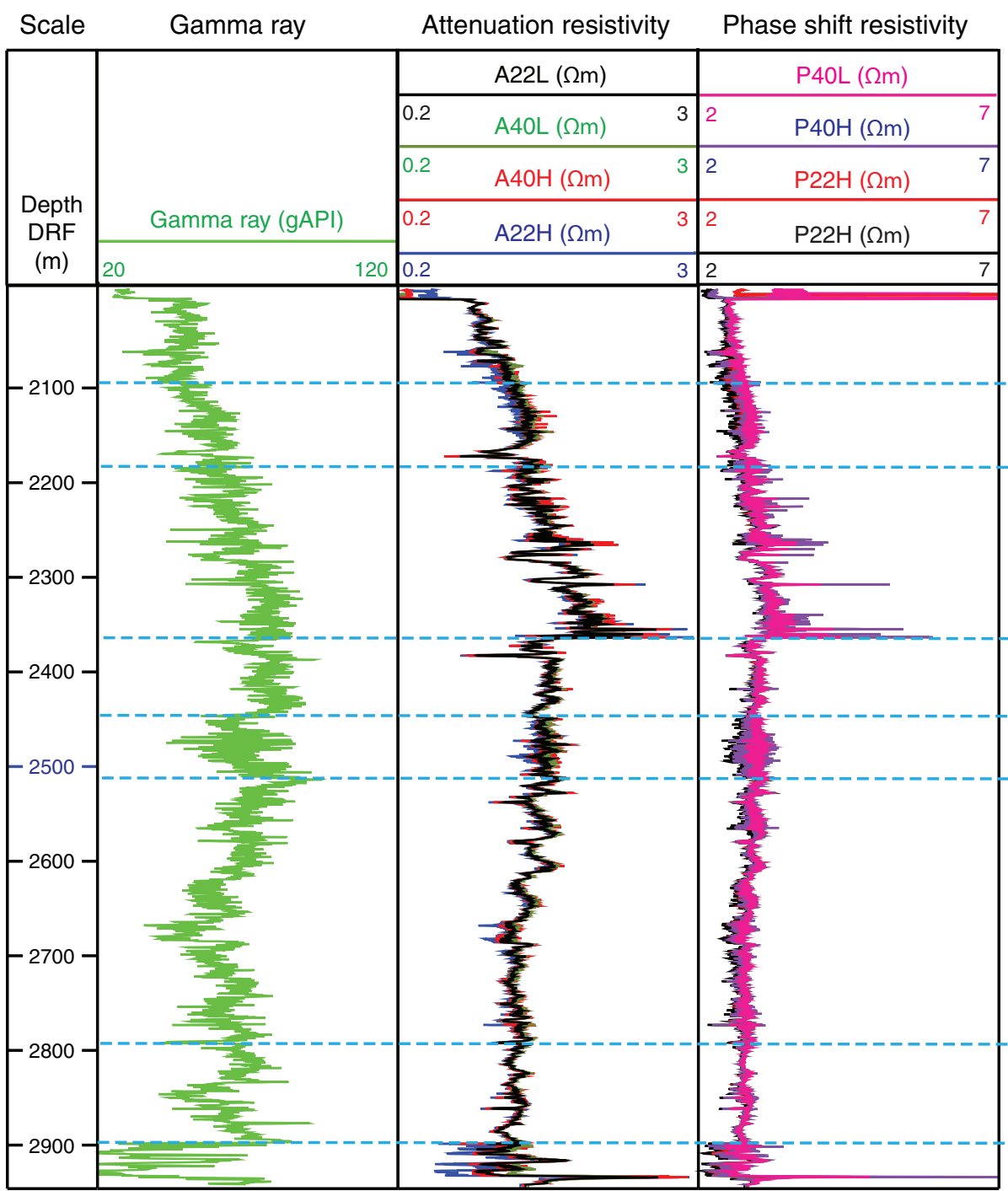
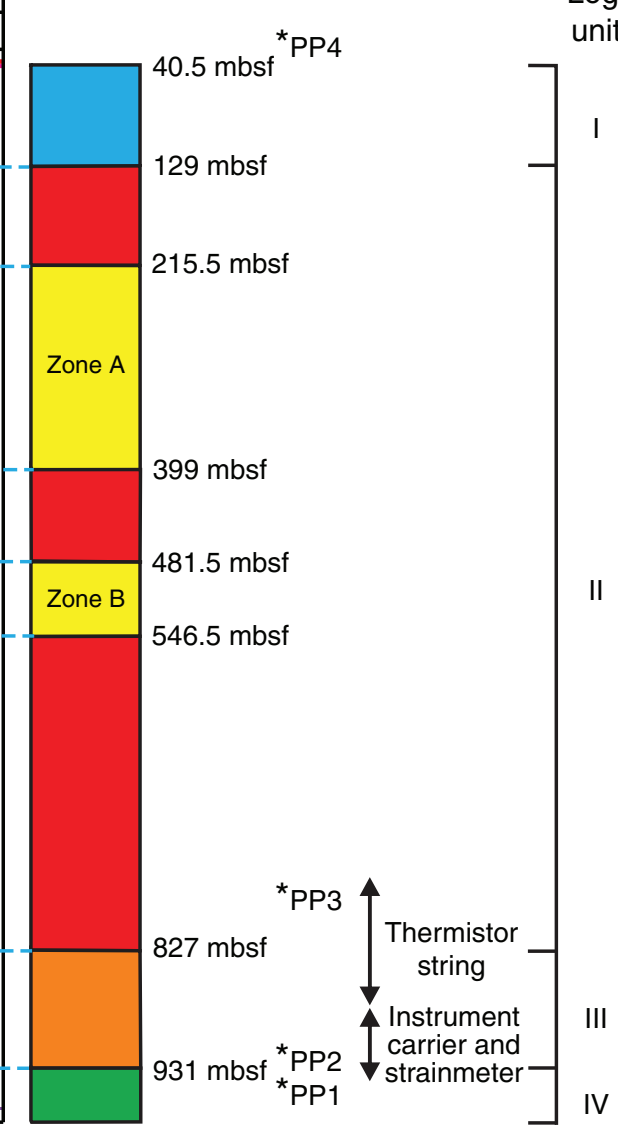

TD: $980 \mathrm{mbsf}$ 
Figure F7. Correlation between gamma ray and resistivity measurements of Hole C0002G and Hole C0002A drilled during Expedition 314. All boundaries identified in Hole C0002A were able to be redefined within a difference of a few meters. The more pronounced characteristics of Expedition 314 measurements could be due to the application of different LWD tools from the arcVISION825.

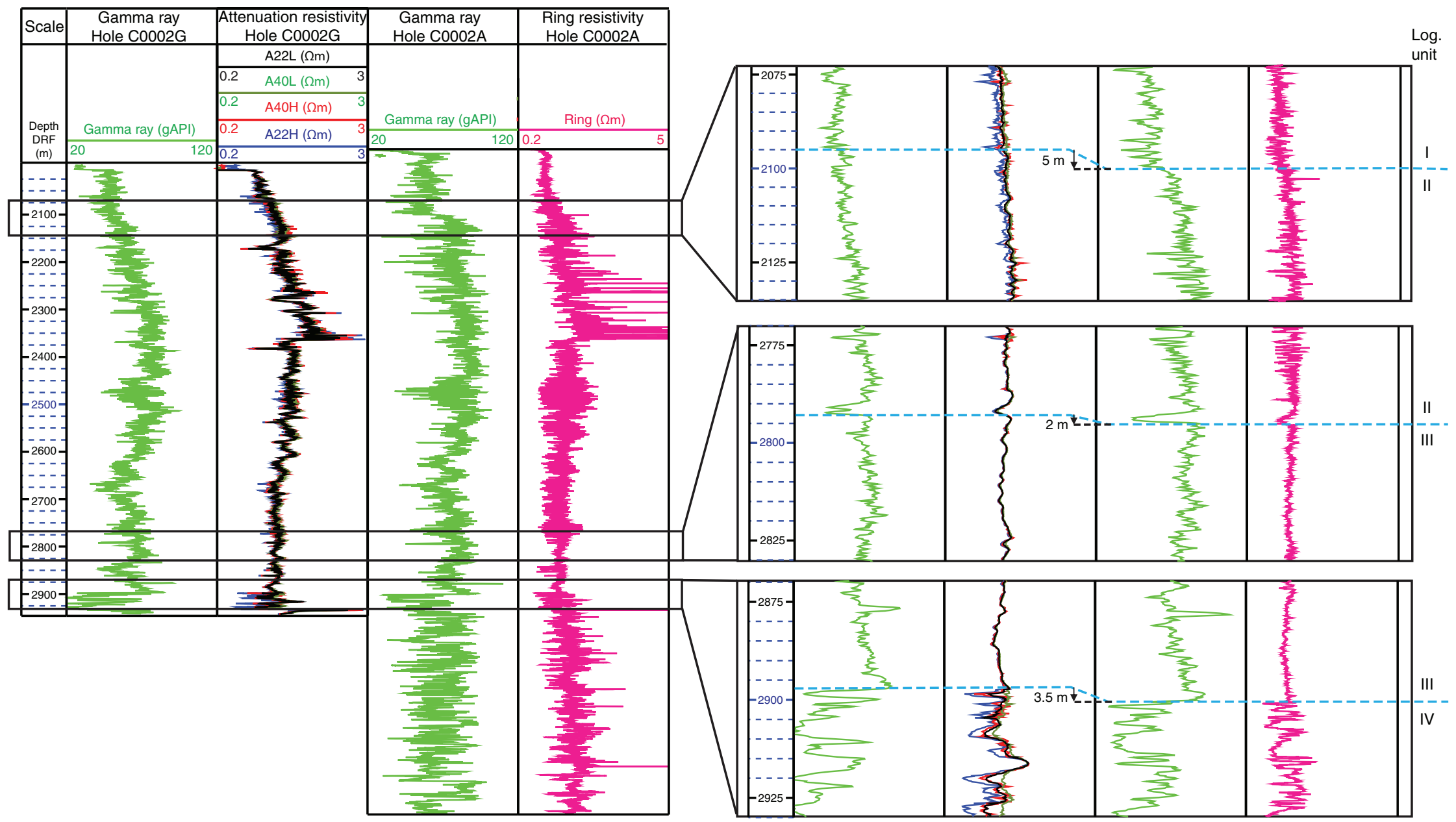


Figure F8. Correlation of LWD/MWD measurements from Holes C0002A and C0002G with 3-D seismic data set from Moore et al. (2007). Most of the transitions indicated by LWD/MWD data sets correspond to distinct amplitude changes of seismic layers (e.g., Unit II Zones A or B). Bottom of Zone A can be clearly attributed to the occurrence of a BSR, which is indicated by a remarkable increase in resistivity. The beginning of the accretionary prism in the seismic data is visible by chaotic, wavy reflectors, which corresponds to the highly oscillating curve progression in the $\mathrm{LWD} / \mathrm{MWD}$ data sets. $\mathrm{IL}=$ in-line, $\mathrm{XL}=$ cross-line.

Hole C0002G

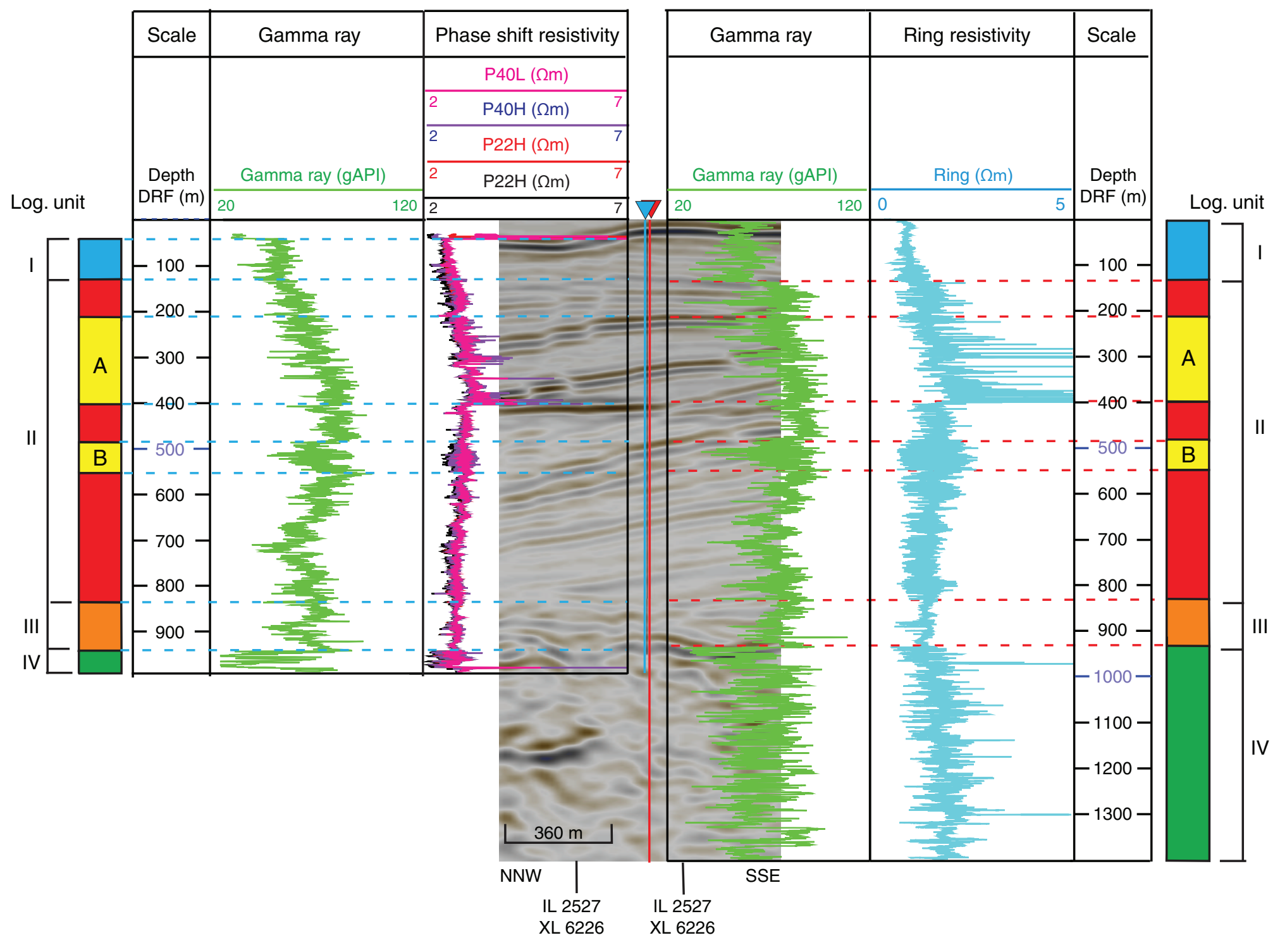


Figure F9. Schematic diagram of long-term borehole observatory, Hole C0002G.

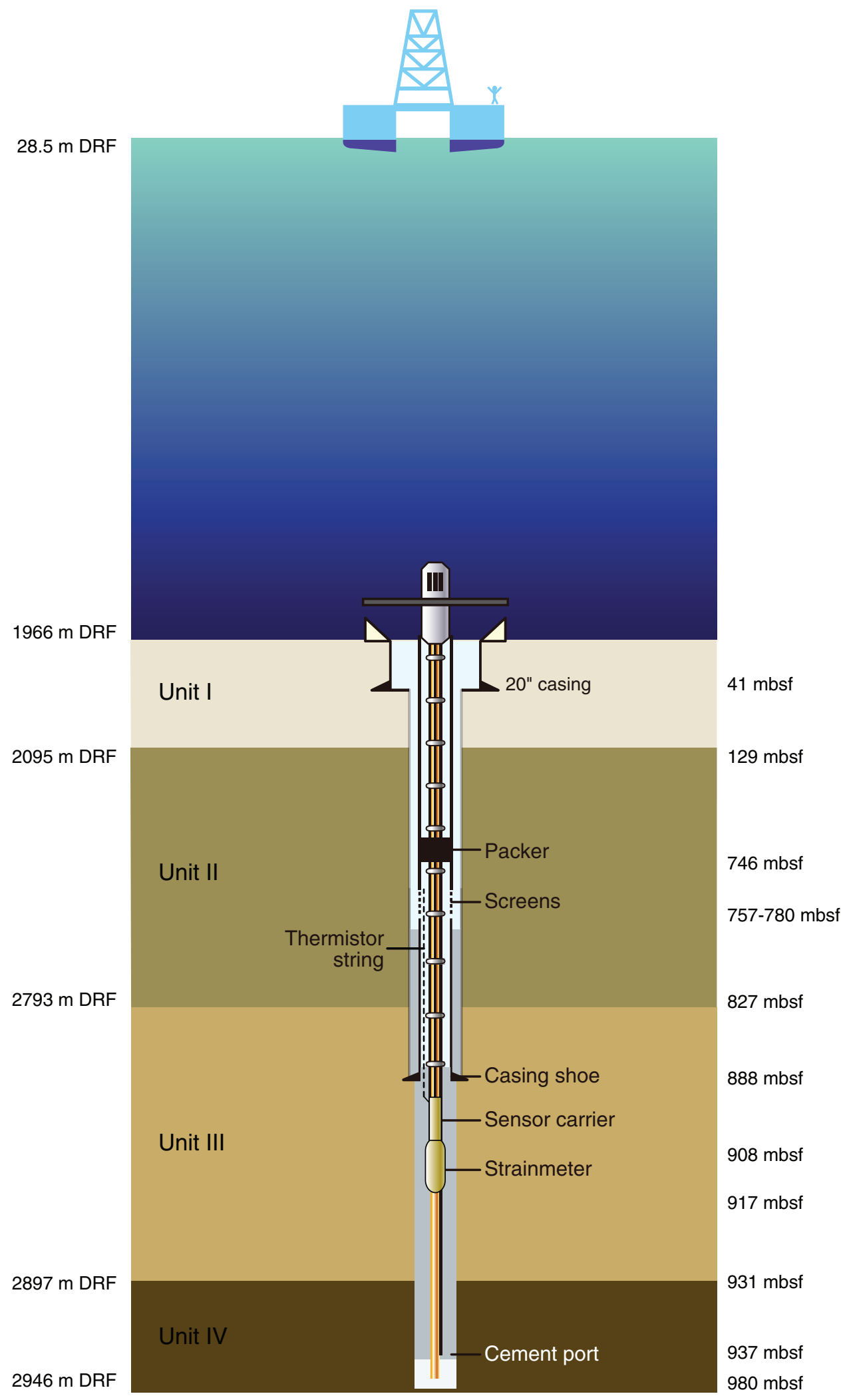


Figure F10. Schematic diagram showing the spacing of centralizers, tie wraps, and steel bands used for strapping to $3 \frac{1}{2}$ inch tubing, shown for a tubing joint. SUS = steel use stainless.

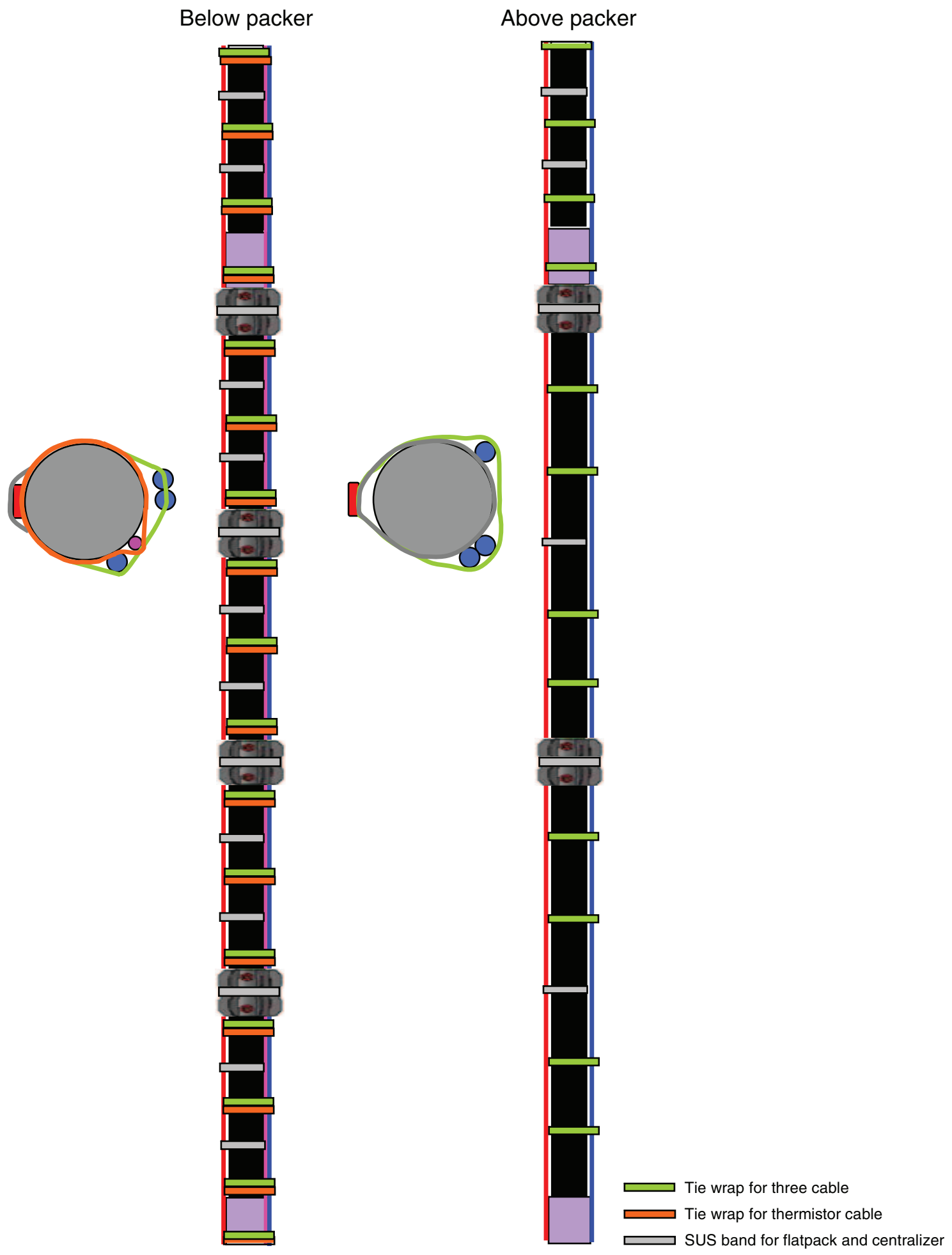


Figure F11. Photos of cable strapping to 31/2 inch tubing, Site C0002. Centralizers were installed to protect cables and flatpack.
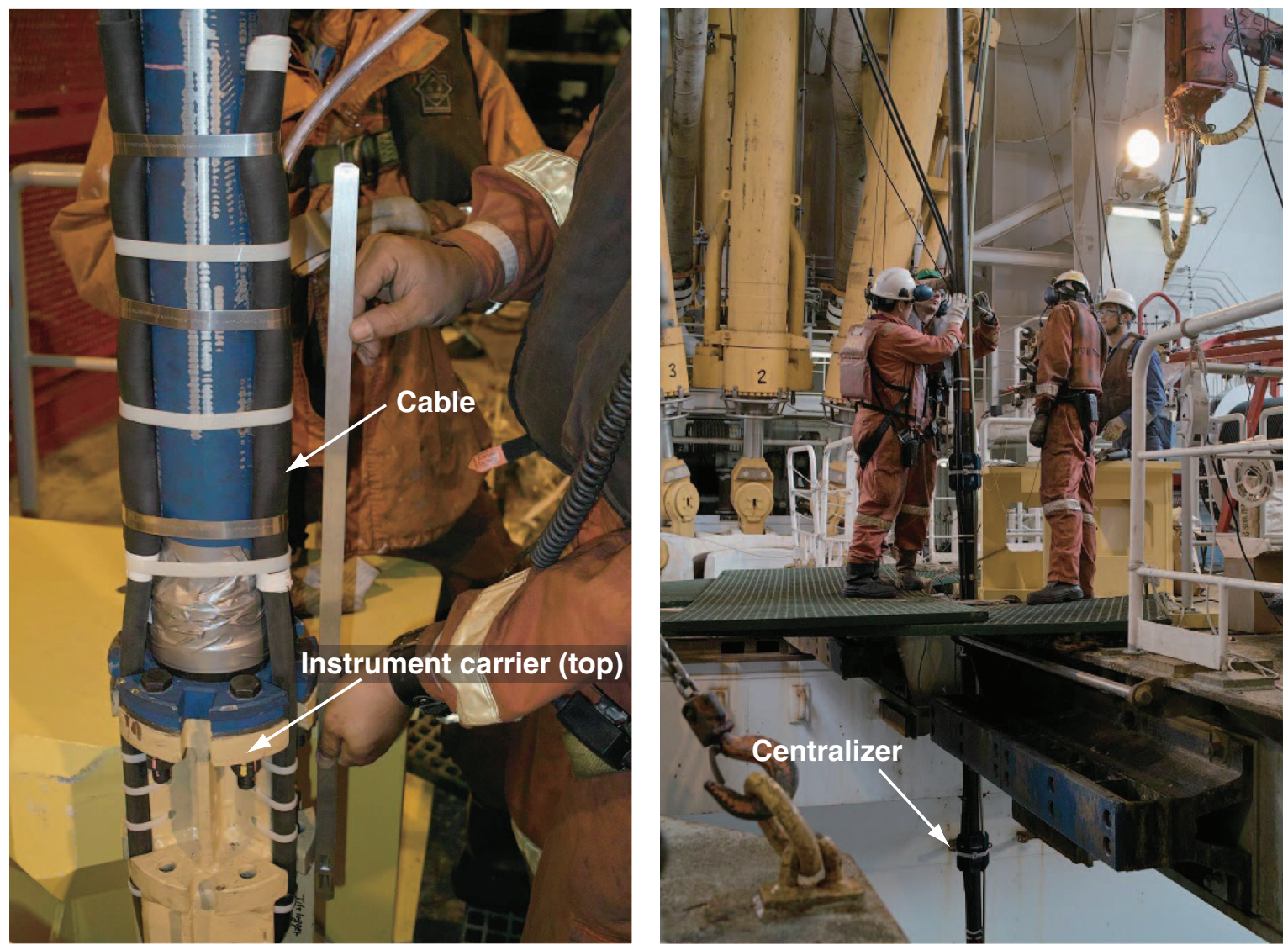
Figure F12. Swellable packer at $1640 \mathrm{~m}, \sim 4$ days after deployment in seawater, Site C0002. ROV = remotely operated vehicle.

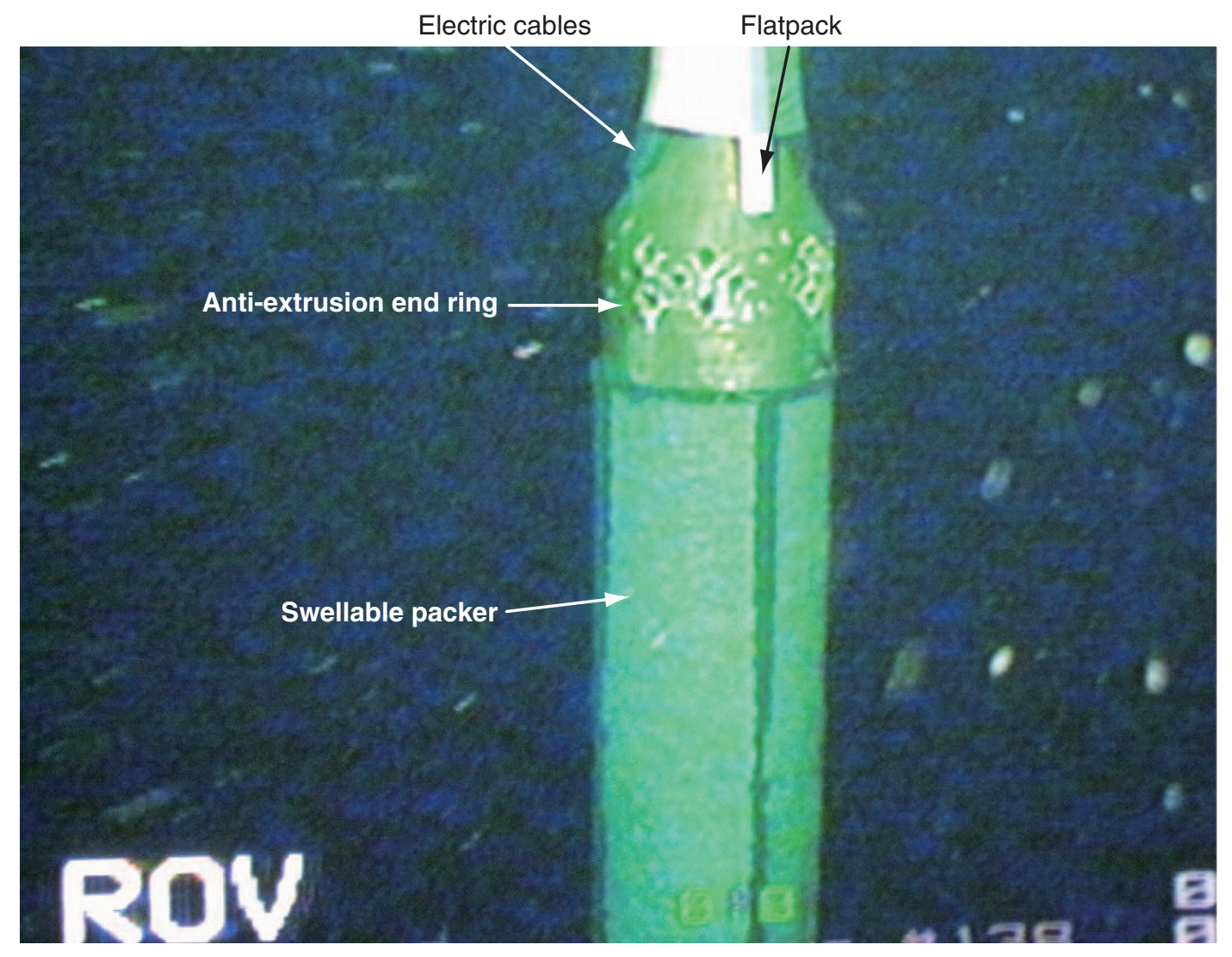


Figure F13. Pressure port with miniscreens, Site C0002.

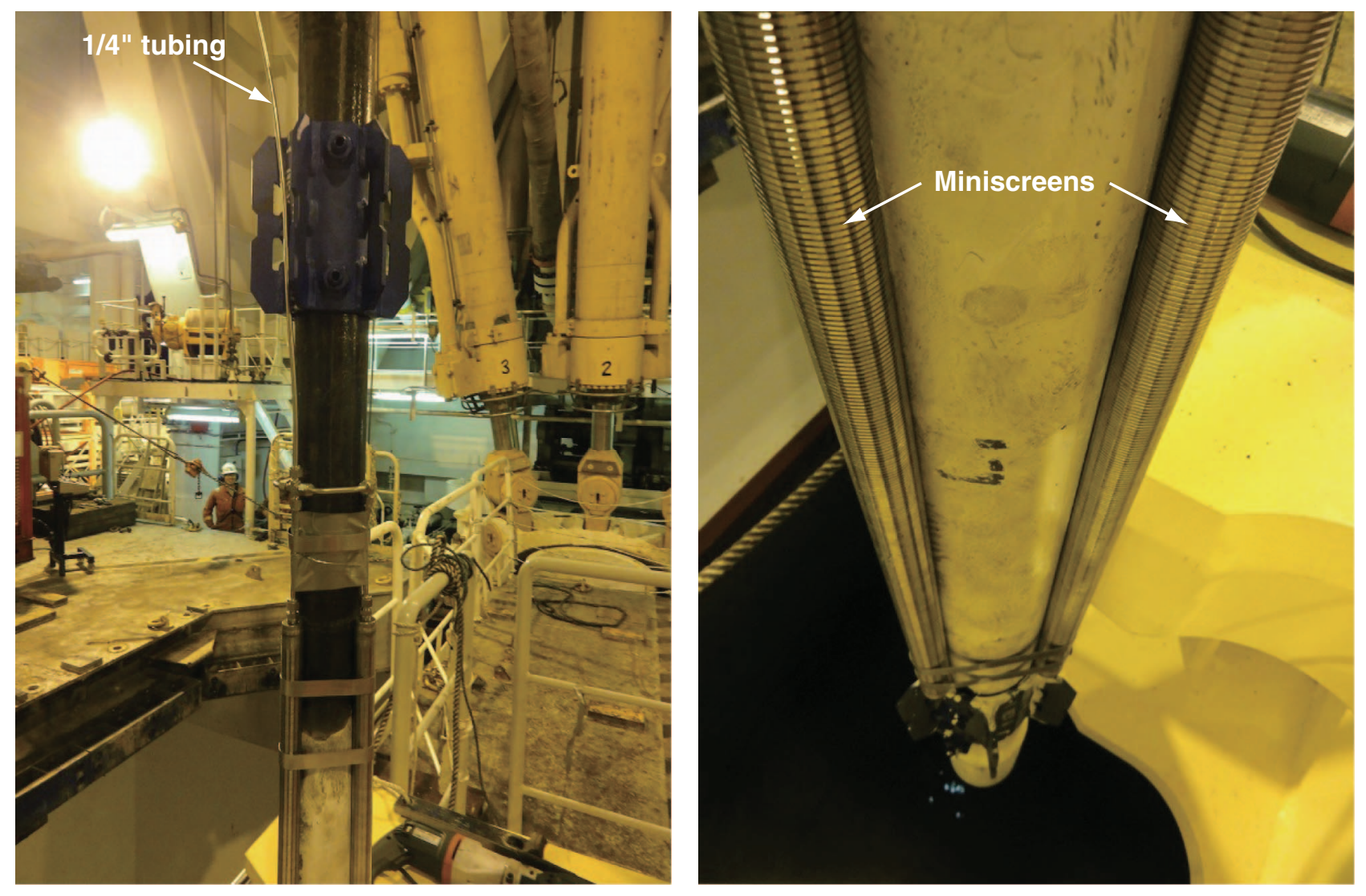


Figure F14. Strainmeter being lowered into the moonpool, Site C0002. Sensing volume is located near the bottom part of the strainmeter.

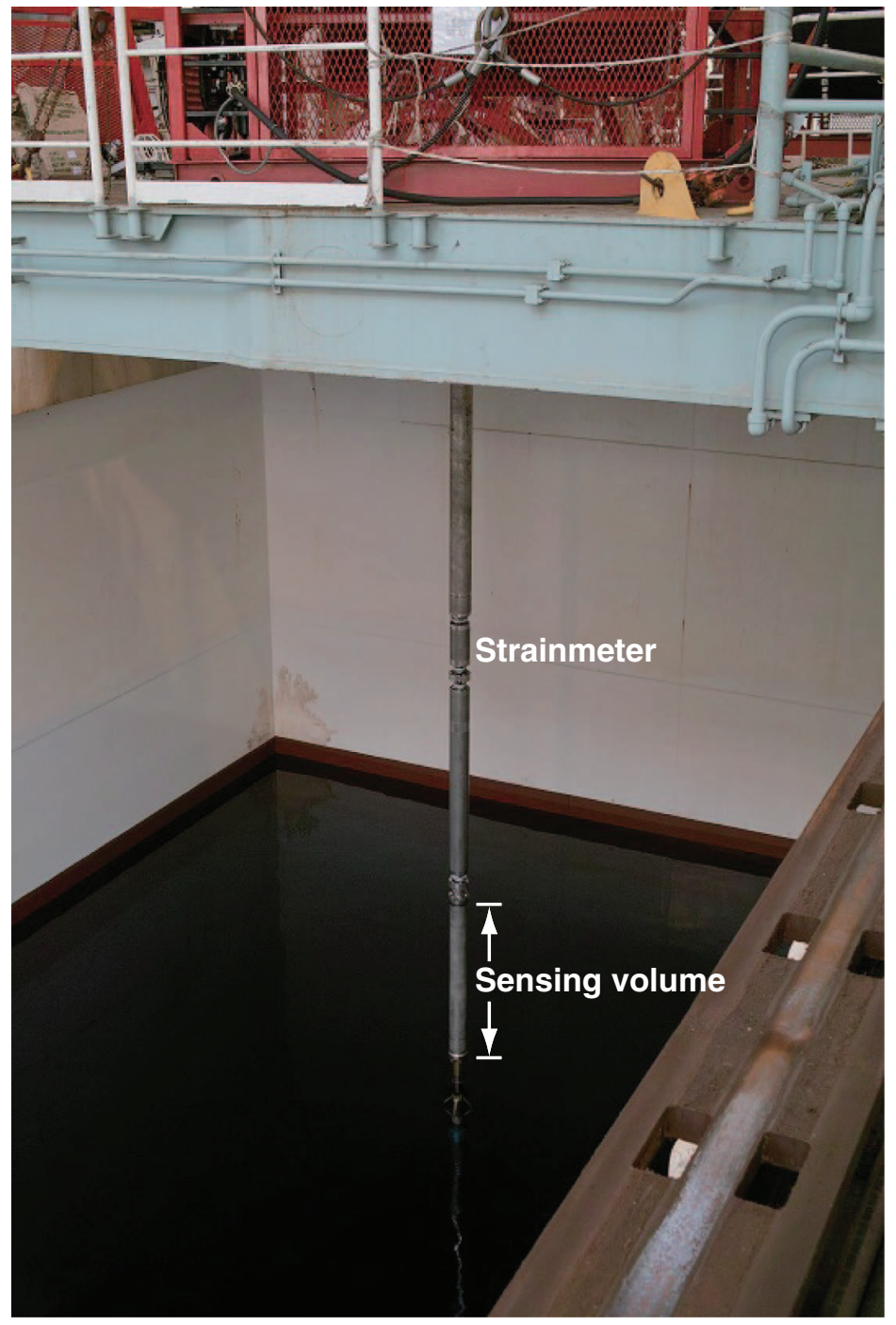


Figure F15. Instrument carrier suspended from rig floor, Site C0002. Instruments housed from the top: tilt combo consisting of geophone and accelerometer module, SAHF digitizer, and LILY tiltmeter and Guralp CMG3T broadband seismometer.

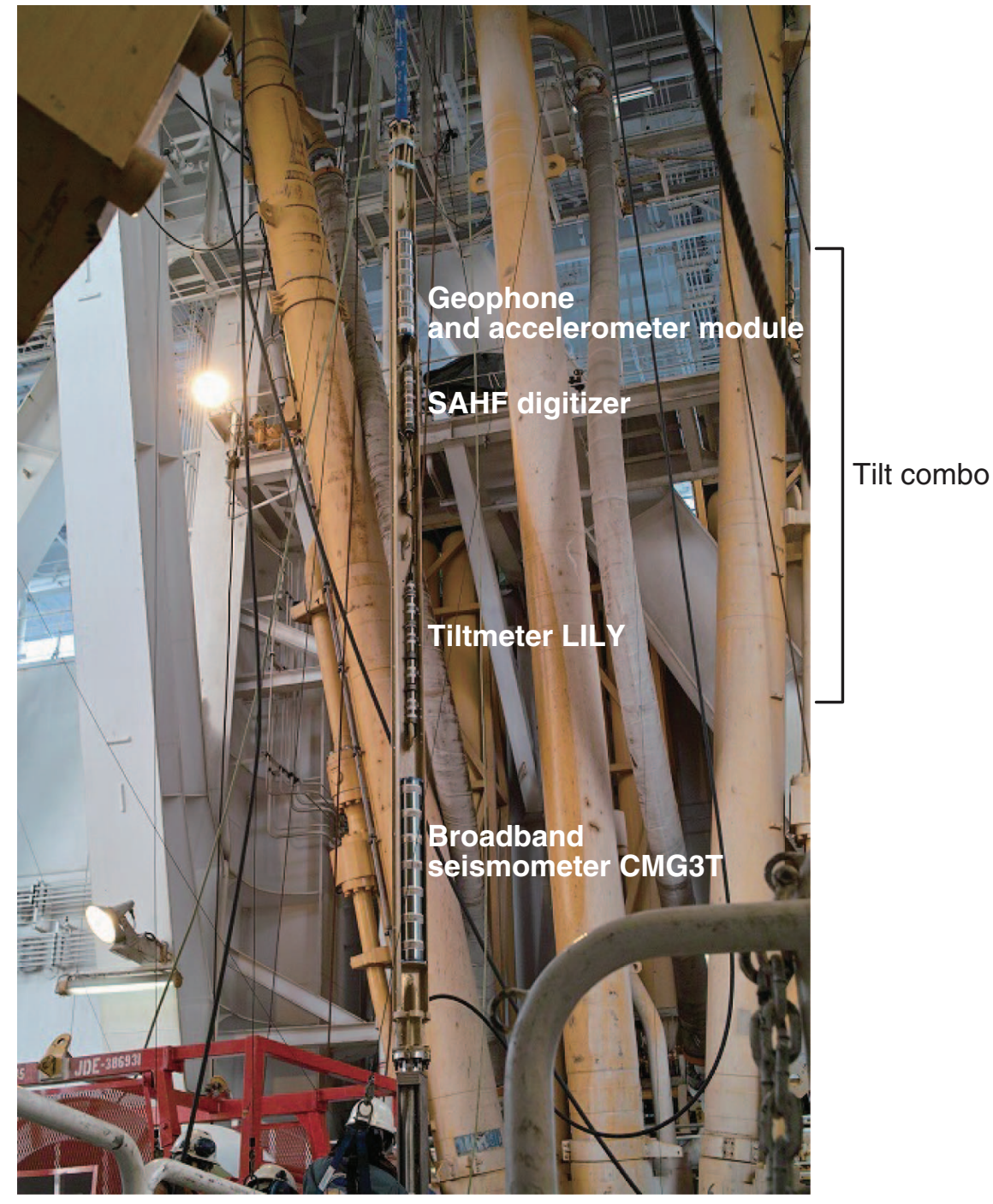


Figure F16. Initial pressure data from Site C0002 CORK observatory during cementing and after starting observation. Borehole pressure Ports PP1PP3 from the bottom and seafloor pressure PF are shown.

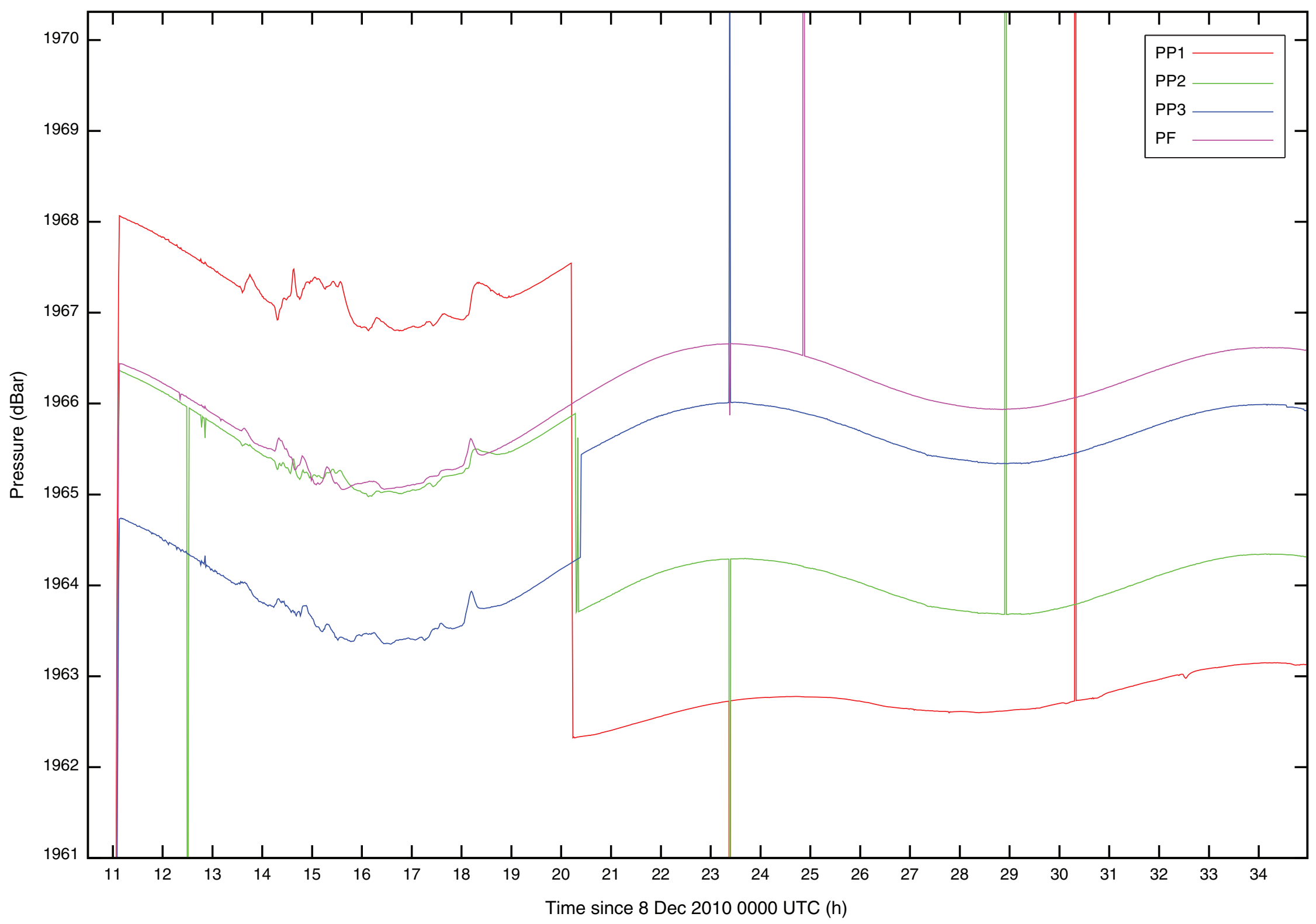


Figure F17. CORK head photographs, Site C0002. A. Pressure data logger bay. B. Ocean Design, Inc. (ODI) underwater mateable connectors for borehole instruments. ROV = remotely operated vehicle.
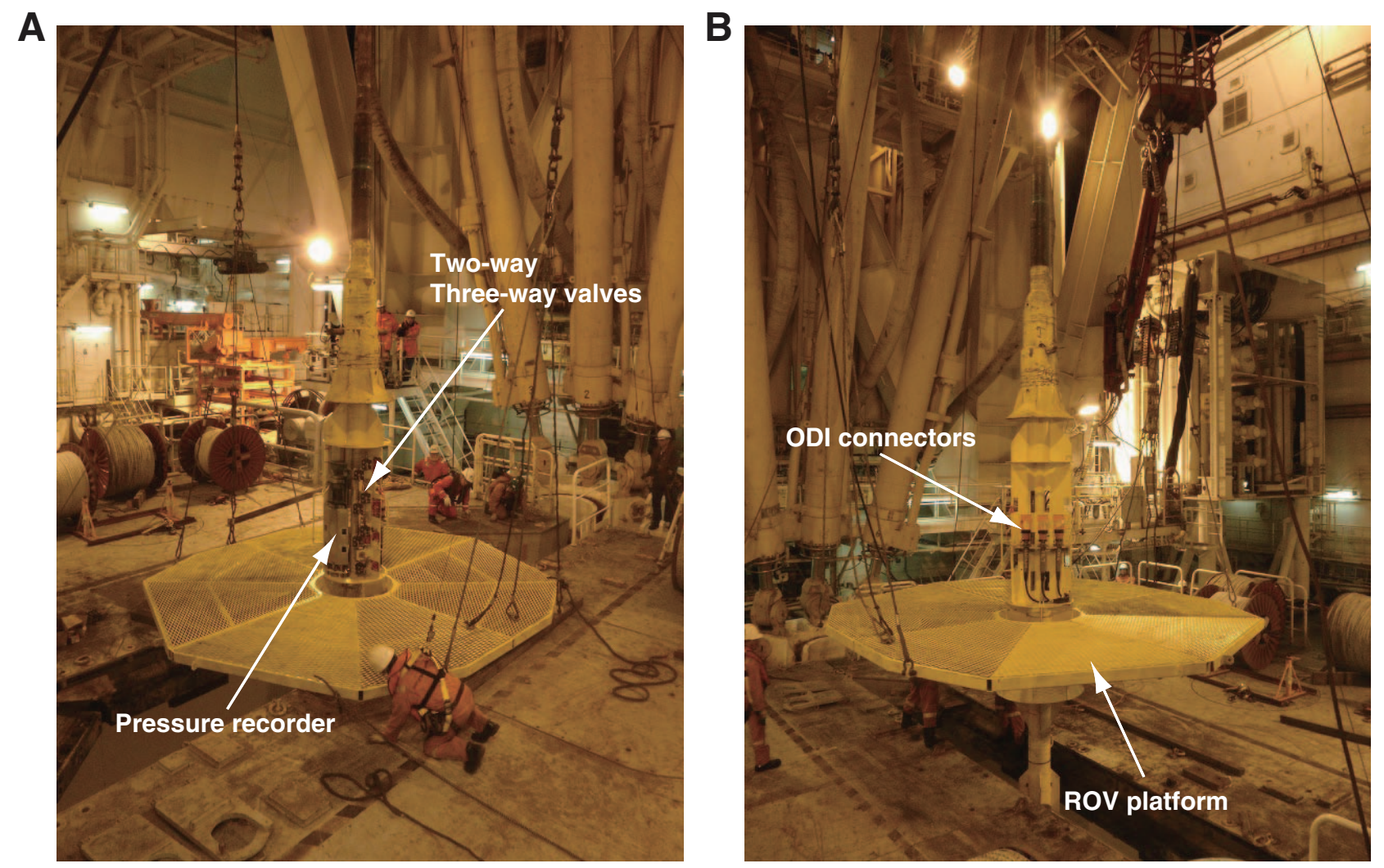
Figure F18. Schematic drawing of CORK head viewed from top, Site C0002.

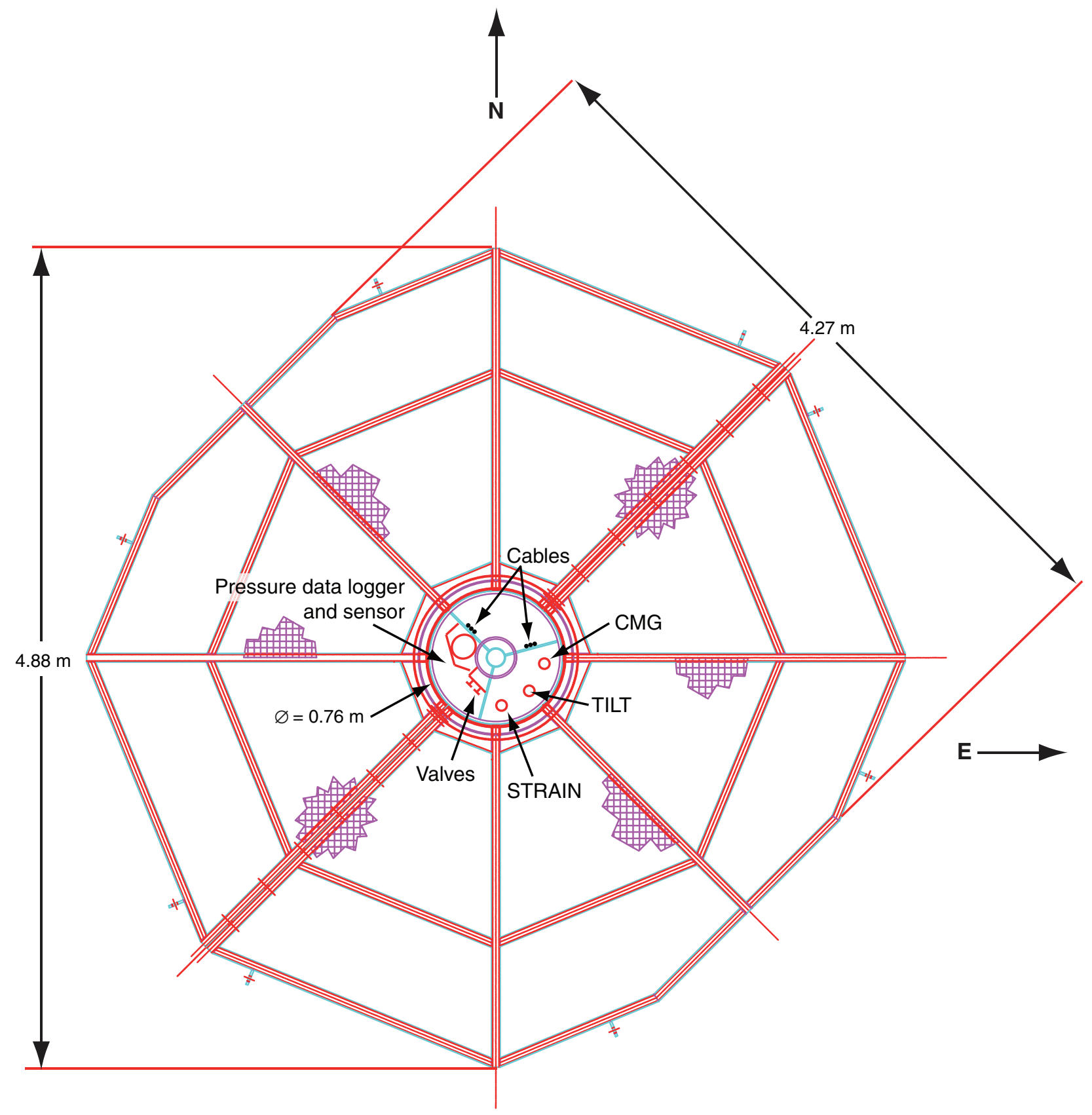


Figure F19. CORK head photographs from remotely operated vehicle (ROV), Site C0002. A. CORK head and ROV platform as they are lowered through the water column. ROV was towed by the platform with a tether rope. B. Downloading pressure data from the sensor carrier in the pressure bay of the CORK head after cementing.

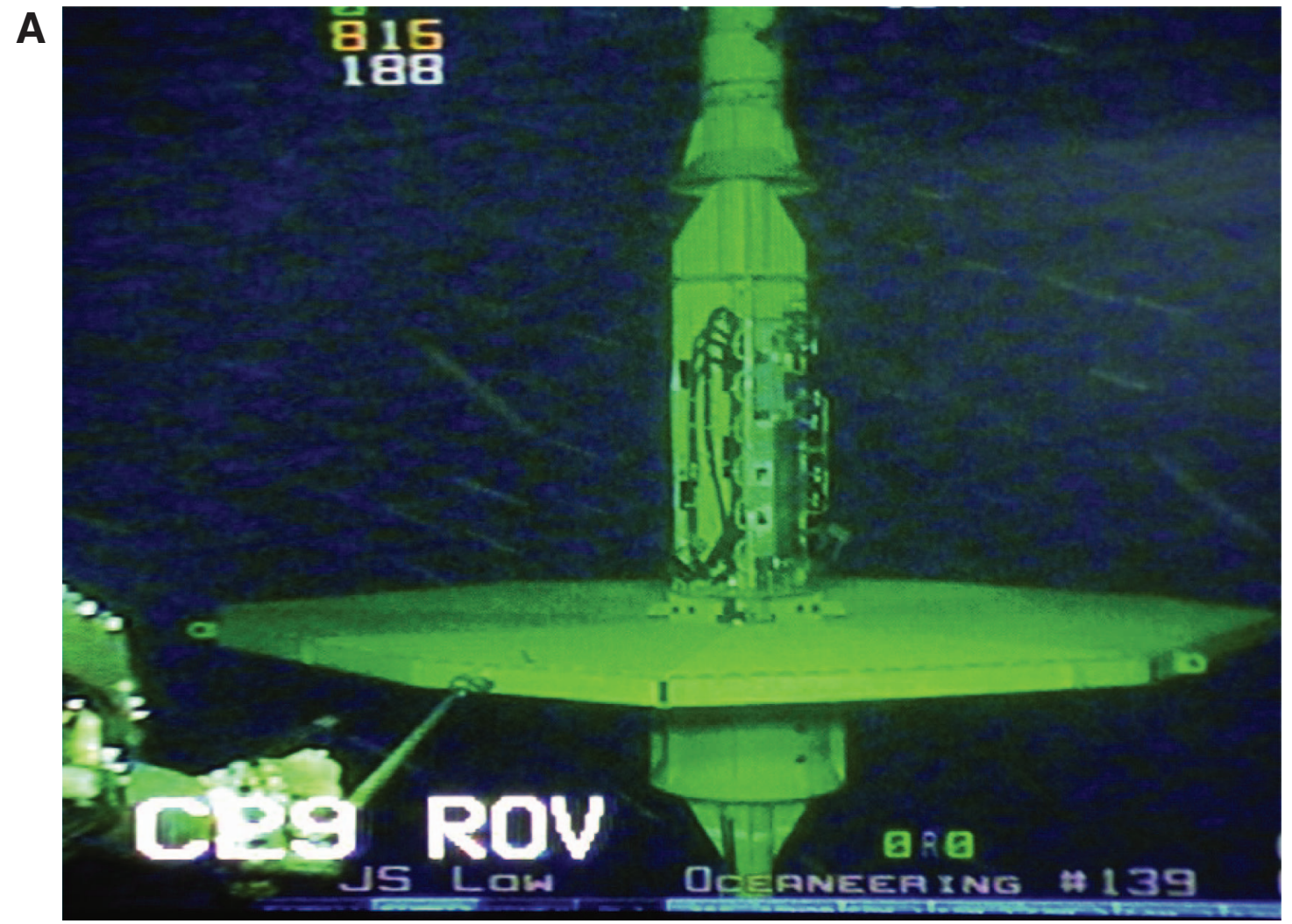

B

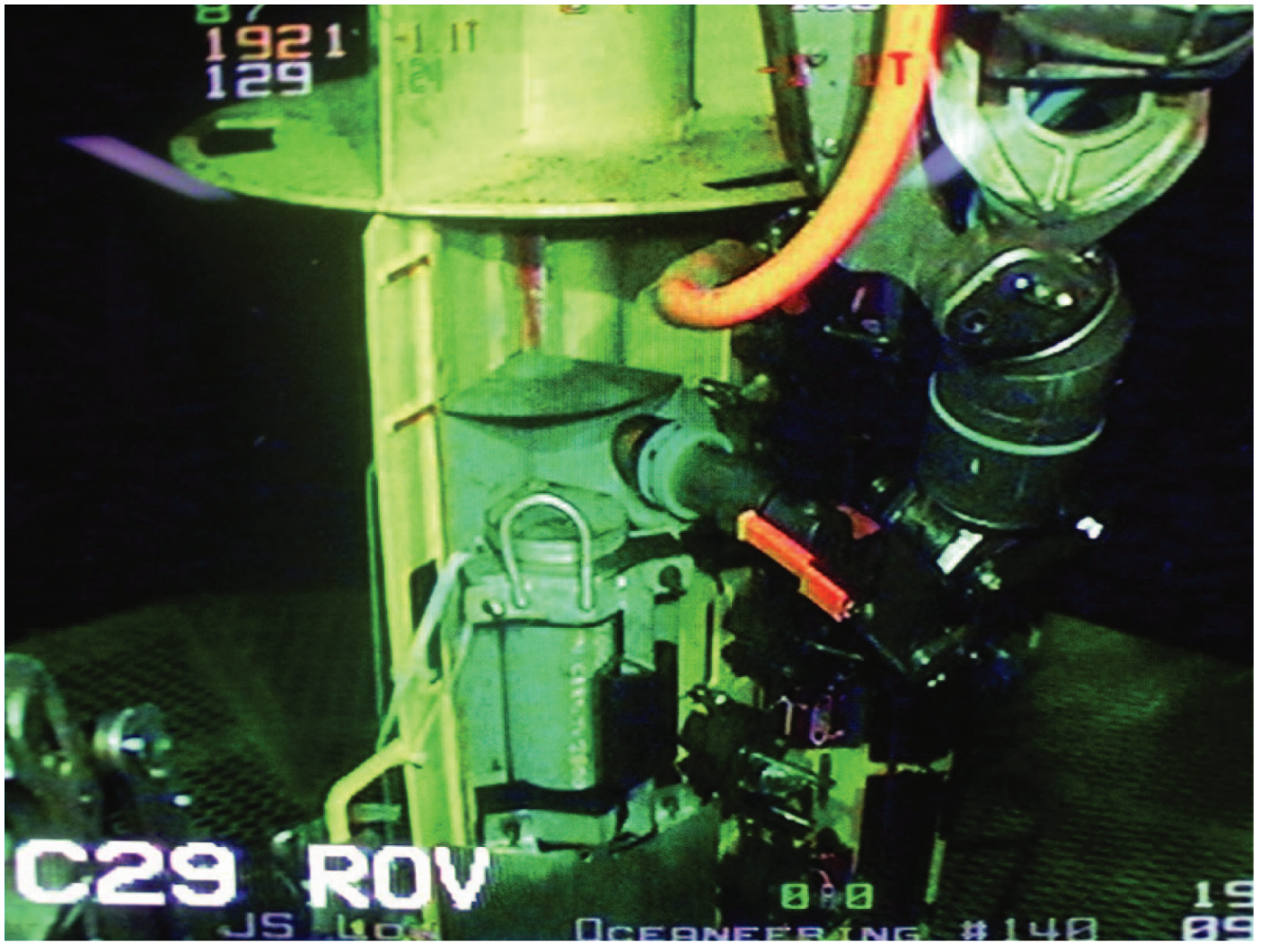


Figure F20. Timeline showing the acceleration forces encountered during lowering drill pipe, drifting to the site, reentry to the wellhead, remotely operated vehicle (ROV) testing the LTBMS sensors, cementing and pulling out of the hole (POOH), and retrieval of the drill pipe at Site C0002. Yellow shading $=$ data during drifting.

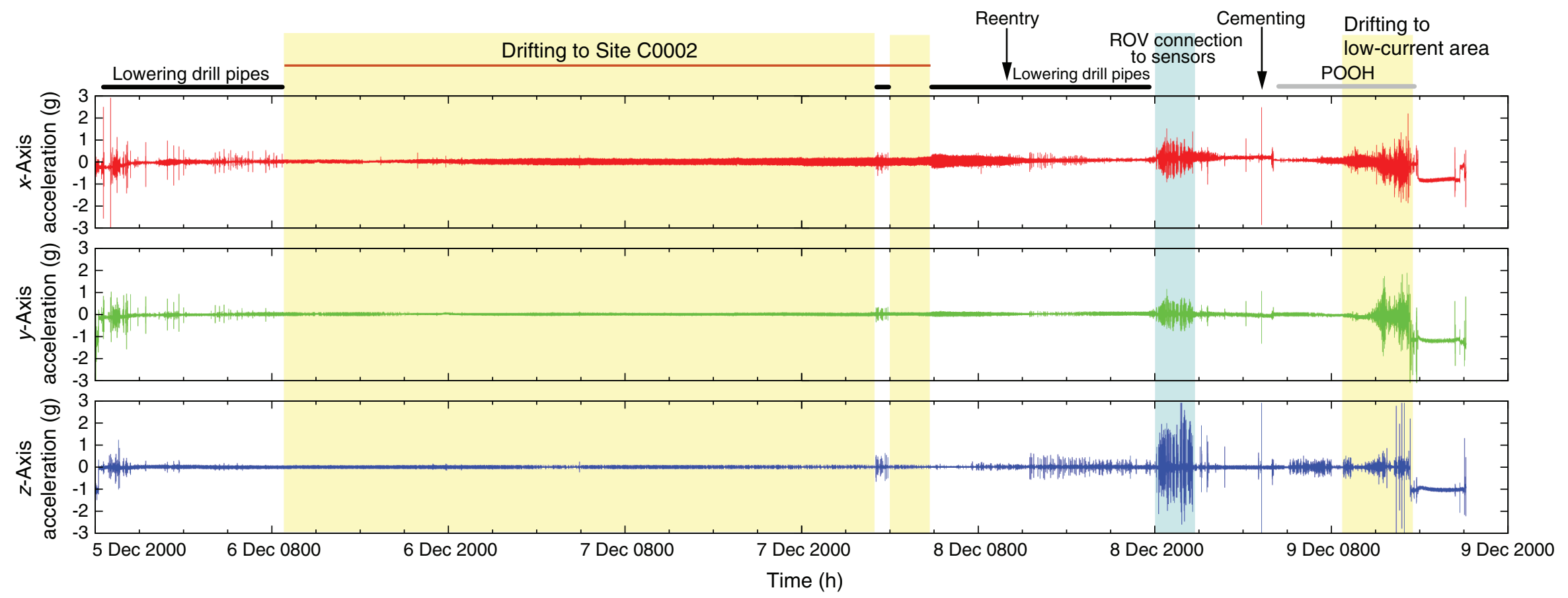


Figure F21. Photograph of ROV capable of testing LTBMS instruments with the program applications and a portable mini-PC, Site C0002.

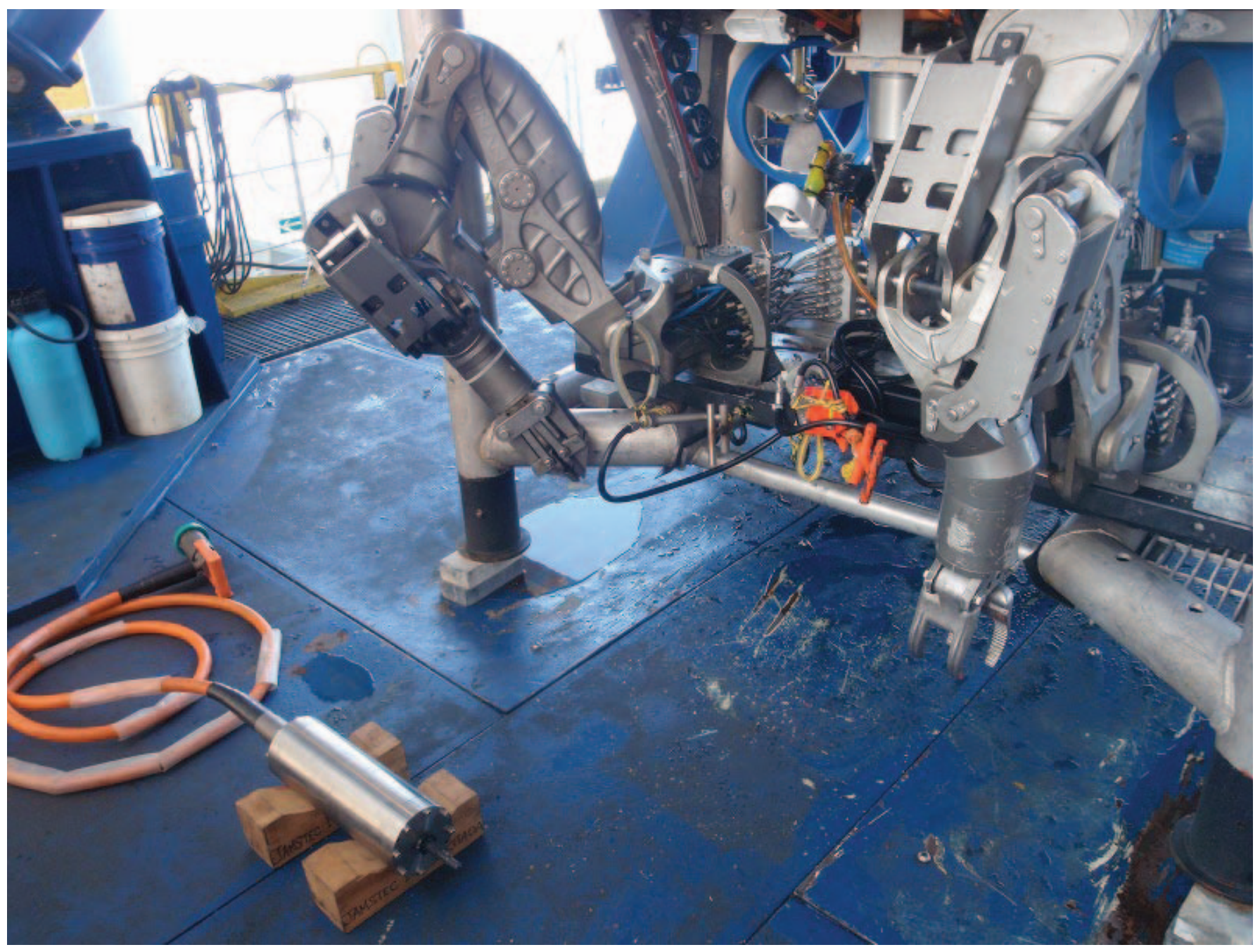


Table T1. Operations summary, Site C0002. (Continued on next three pages.)

\begin{tabular}{|c|c|c|c|c|c|}
\hline $\begin{array}{l}\text { Hole C0002G } \\
\text { Latitude: } 33^{\circ} 18.0130^{\prime} \mathrm{N} \\
\text { Longitude: } 136^{\circ} 38.1500^{\prime} \mathrm{E} \\
\text { Water depth (m): } 1936 \\
\text { Seafloor (m): } 1966 \text { DRF (1937.5 mbsl) } \\
20 \text { inch conductor pipe shoe (m): } 2007 \text { DRF ( } 41 \text { mbs } \\
\text { 9-5/8 inch casing screen interval (m): } 2723-2746 \text { DR } \\
\text { 9-5/8 inch casing shoe (m): } 2854 \text { DRF ( } 888 \text { mbsf) } \\
\text { TD }(\mathrm{m}): 2946 \text { DRF ( } 980 \text { mbsf) }\end{array}$ & $\begin{array}{l}f) \\
F(757-78\end{array}$ & o mbsf) & & & \\
\hline \multirow[b]{2}{*}{ Operation } & \multicolumn{2}{|c|}{ Start } & \multicolumn{2}{|c|}{ Depth DSF $(\mathrm{m})$} & \multirow[b]{2}{*}{ Comments } \\
\hline & $\begin{array}{l}\text { Date } \\
(2010)\end{array}$ & $\begin{array}{l}\text { Local time } \\
\text { (h) }\end{array}$ & $\begin{array}{l}\text { Deptn } \\
\text { Top }\end{array}$ & $\frac{D S F(m)}{\text { Bottom }}$ & \\
\hline \multicolumn{3}{|l|}{ Hole C0002G } & 0 & 980 & \\
\hline Prep tool, rig up, and RIH & $13 \mathrm{Nov}$ & 0030 & & & Lower Big Head transducers and check transponders \\
\hline Transit to LCA & $13 \mathrm{Nov}$ & 0130 & & & Make up jetting $\mathrm{BHA}$, prepare 20 inch conductor casing \\
\hline Run 20 inch conductor casing & $13 \mathrm{Nov}$ & $\begin{array}{l}0615 \\
1100\end{array}$ & & & $\begin{array}{l}\text { Pick up } 20 \text { inch casing shoe jetting joint } \\
\text { Pick up Jetting BHA and run into } 20 \text { inch casing }\end{array}$ \\
\hline Run mudmat into moonpool & $13 \mathrm{Nov}$ & 1100 & & & \\
\hline Pick up and secure mudmat on working cart & $13 \mathrm{Nov}$ & 1300 & & & Current increase, so necessary to recover mudmat \\
\hline Move vessel $21 \mathrm{nmi}$ northwest & 13 Nov & 1330 & & & Reach LCA at $1800 \mathrm{~h}$ \\
\hline Resume running 20 inch casing to $110 \mathrm{~m}$ DRF & $13 \mathrm{Nov}$ & 1800 & & & Dove ROV to confirm jet sub projection \\
\hline Begin attaching and terminating anti-VIV ropes & $13 \mathrm{Nov}$ & 2200 & & & \\
\hline Resume running 20 inch casing to $1513 \mathrm{~m} \mathrm{DRF}$ & $13 \mathrm{Nov}$ & 2330 & & & \\
\hline Run 20 inch conductor casing & $14 \mathrm{Nov}$ & 0330 & & & Run to $1860 \mathrm{~m}$ DRF while attaching ropes \\
\hline Dive ROV & $14 \mathrm{Nov}$ & 1745 & & & \\
\hline Monitor drill string for VIV & $14 \mathrm{Nov}$ & 2030 & & & Drifting to Site C0002 \\
\hline Resume running 20 inch casing & $15 \mathrm{Nov}$ & 1000 & & & Run to 1956 m DRF \\
\hline Tag seafloor, confirm hole position & $15 \mathrm{Nov}$ & 1215 & & & ROV survey of seabed \\
\hline Jet-in 20 inch casing & $15 \mathrm{Nov}$ & 1300 & 0 & 40.9 & Jet to $40.9 \mathrm{mbsf}$ \\
\hline Release cart & $15 \mathrm{Nov}$ & 1630 & & & \\
\hline Pick up BHA to $1970 \mathrm{~m} \mathrm{DRF}$ & $15 \mathrm{Nov}$ & 1730 & & & \\
\hline $\mathrm{POOH}$ jetting assembly to $1156 \mathrm{~m}$ DRF & $15 \mathrm{Nov}$ & 1830 & & & Begin removing anti-VIV ropes \\
\hline Recover ROV on deck & $15 \mathrm{Nov}$ & 2130 & & & \\
\hline Finish anti-VIV ropes at $1430 \mathrm{~m}$ DRF & $15 \mathrm{Nov}$ & 2315 & & & \\
\hline $\mathrm{POOH}$ jetting assembly to surface & $16 \mathrm{Nov}$ & 0330 & & & \\
\hline Make up lower guide horn in moonpool & $16 \mathrm{Nov}$ & 1045 & & & \\
\hline Make up and RIH 12-1/4 inch BHA to $92 \mathrm{~m}$ DRF & $16 \mathrm{Nov}$ & 1900 & & & \\
\hline Run shallow test for LWD and MWD & $16 \mathrm{Nov}$ & 2100 & & & \\
\hline Start drifting & $16 \mathrm{Nov}$ & 2245 & & & \\
\hline RIH to $1800 \mathrm{~m}$ DRF & $17 \mathrm{Nov}$ & 0415 & & & $\begin{array}{l}\text { RIH from } 92 \text { to } 1800 \mathrm{~m} \text { DRF while drifting to Hole } \\
\text { C0002G }\end{array}$ \\
\hline Drift to Hole C0002G & $17 \mathrm{Nov}$ & 0815 & & & \\
\hline Run to 1965 m DRF & $17 \mathrm{Nov}$ & 0945 & & & \\
\hline Reenter wellhead & $17 \mathrm{Nov}$ & 0945 & & & \\
\hline Ream to $2007 \mathrm{~m}$ DRF & $17 \mathrm{Nov}$ & 1030 & & & \\
\hline Drill 12-1/4 inch LWD hole to $2267 \mathrm{~m}$ DRF & $17 \mathrm{Nov}$ & 2400 & 0 & 301 & ROP $40 \mathrm{~m} / \mathrm{h}$ \\
\hline Drill $12-1 / 4$ inch LWD hole to $2573 \mathrm{~m} \mathrm{DRF}$ & $18 \mathrm{Nov}$ & 1145 & 0 & 607 & ROP $40 \mathrm{~m} / \mathrm{h}$. Pump $5 \mathrm{~m}^{3} \mathrm{Hi}$-Vis mud every half-stand \\
\hline Sweep and circulate to clean hole & $18 \mathrm{Nov}$ & 1230 & & & $\mathrm{Hi}$-Vis mud $10 \mathrm{~m}^{3}$ \\
\hline Short trip to 20 inch casing shoe & $18 \mathrm{Nov}$ & 1430 & & & \\
\hline Run back to bottom & $18 \mathrm{Nov}$ & 1830 & & & \\
\hline Resume drilling $12-1 / 4$ inch hole to $2675 \mathrm{~m}$ DRF & $18 \mathrm{Nov}$ & 2400 & 0 & 709 & Below $2620 \mathrm{~m}$ DRF ROP reduced to $30 \mathrm{~m} / \mathrm{h}$ \\
\hline Drill 12-1/4 inch LWD hole to 2858 m DRF & $19 \mathrm{Nov}$ & 1045 & 0 & 892 & ROP controlled at $30 \mathrm{~m} / \mathrm{h}$ \\
\hline Sweep Hi-Vis mud and circulate to clean hole & 19 Nov & 1145 & & & Sweep $10 \mathrm{~m}^{3}$ \\
\hline Spot $60 \mathrm{~m}^{3} \mathrm{Hi}$-Vis mud & $19 \mathrm{Nov}$ & 1230 & & & \\
\hline $\mathrm{POOH}$ to $1810 \mathrm{~m}$ DRF & $19 \mathrm{Nov}$ & 1530 & & & \\
\hline ROV on deck & $19 \mathrm{Nov}$ & 1640 & & & \\
\hline Resume $\mathrm{POOH}$ while drifting & $19 \mathrm{Nov}$ & 2015 & & & \\
\hline $\mathrm{POOH}$ to rig floor & $20 \mathrm{Nov}$ & 0100 & & & Lay out $12-1 / 4$ inch BHA \\
\hline Make up and RIH 10-5/8 inch LWD BHA & $20 \mathrm{Nov}$ & 0800 & & & Run to $1800 \mathrm{~m}$ DRF \\
\hline $\begin{array}{l}\text { Move to location, dive ROV } 1 \mathrm{nmi} \text { from Hole } \\
\text { C0002G }\end{array}$ & $20 \mathrm{Nov}$ & 1030 & & & \\
\hline Resume RIH to 1993 m DRF & $20 \mathrm{Nov}$ & 1130 & & & \\
\hline RIH to $2830 \mathrm{~m} \mathrm{DRF}$ & $20 \mathrm{Nov}$ & 1530 & & & \\
\hline Relog from 2788 to 2804 and 2833 to $2858 \mathrm{~m} \mathrm{DRF}$ & $20 \mathrm{Nov}$ & 1900 & & & \\
\hline Drill 10-5/8 inch LWD hole to 2912 m DRF & $20 \mathrm{Nov}$ & 2400 & 0 & 946 & Average ROP $22.1 \mathrm{~m} / \mathrm{h}$ \\
\hline Drill 10-5/8 inch LWD hole to $2946 \mathrm{~m} \mathrm{DRF}$ & $21 \mathrm{Nov}$ & 0230 & 0 & 980 & Average ROP $14.6 \mathrm{~m} / \mathrm{h}$ \\
\hline Circulate to clean hole, Hi-Vis mud & $21 \mathrm{Nov}$ & 0445 & & & \\
\hline $\mathrm{POOH}$ to $2862 \mathrm{~m}$ DRF, relog LWD from $2859 \mathrm{~m}$ DRF & $21 \mathrm{Nov}$ & 0600 & & & LWD data merge for $2859-2830 \mathrm{~m}$ DRF LWD run \\
\hline Trip to $2500 \mathrm{~m} \mathrm{DRF}$ & $21 \mathrm{Nov}$ & 0715 & & & \\
\hline
\end{tabular}


Table T1 (continued). (Continued on next page.)

\begin{tabular}{|c|c|c|c|c|c|}
\hline \multirow[b]{3}{*}{ Operation } & \multicolumn{2}{|c|}{ Start } & \multirow{2}{*}{\multicolumn{2}{|c|}{ Depth DSF (m) }} & \multirow[b]{3}{*}{ Comments } \\
\hline & \multirow{2}{*}{$\begin{array}{l}\text { Date } \\
(2010)\end{array}$} & \multirow{2}{*}{$\begin{array}{l}\text { Local time } \\
\quad(h)\end{array}$} & & & \\
\hline & & & Top & Bottom & \\
\hline Ream to bottom & $21 \mathrm{Nov}$ & 0900 & & & \\
\hline Circulate bottoms up & $21 \mathrm{Nov}$ & 1200 & & & Sweep Hi-Vis mud, $10 \mathrm{~m}^{3}$ \\
\hline Run back to bottom & $21 \mathrm{Nov}$ & 1815 & & & No excess drag \\
\hline Sweep out Hi-Vis mud $10 \mathrm{~m}^{3}$ & $21 \mathrm{Nov}$ & 1900 & & & \\
\hline Spot Hi-Vis mud $104 \mathrm{~m}^{3}$ & $21 \mathrm{Nov}$ & 2015 & & & \\
\hline $\mathrm{POOH}$ to $1870 \mathrm{~m} \mathrm{DRF}$ & $21 \mathrm{Nov}$ & 2400 & & & \\
\hline Continue $\mathrm{POOH} 10-5 / 8$ inch LWD BHA & $22 \mathrm{Nov}$ & 0615 & & & \\
\hline Prepare for running casing & $22 \mathrm{Nov}$ & 0845 & & & \\
\hline Run $9-5 / 8$ inch casing to $130 \mathrm{~m} \mathrm{DRF}$ & $22 \mathrm{Nov}$ & 1730 & & & \\
\hline Replace PS-30 to manual slip & $22 \mathrm{Nov}$ & 1830 & & & \\
\hline Drift to Hole C0002G & $22 \mathrm{Nov}$ & 2300 & & & \\
\hline Resume running 9-5/8 inch casing to $885 \mathrm{~m} \mathrm{DRF}$ & $22 \mathrm{Nov}$ & 2315 & & & \\
\hline Run inner string to float collar & $23 \mathrm{Nov}$ & 0300 & & & \\
\hline Pick up DP S150 with XO sub & $23 \mathrm{Nov}$ & 0345 & & & \\
\hline Dive ROV & $23 \mathrm{Nov}$ & 0510 & & & \\
\hline $\begin{array}{l}\text { Connect casing hanger running tool to } 9-5 / 8 \text { inch } \\
\text { casing hanger }\end{array}$ & 23 Nov & 0530 & & & \\
\hline Break circulation with leak test & $23 \mathrm{Nov}$ & 0600 & & & \\
\hline Recover ROV on deck & $23 \mathrm{Nov}$ & 0625 & & & \\
\hline Run $9-5 / 8$ inch casing to $1360 \mathrm{~m} \mathrm{DRF}$ & $23 \mathrm{Nov}$ & 0715 & & & \\
\hline Run $9-5 / 8$ inch casing to $1830 \mathrm{~m} \mathrm{DRF}$ & $23 \mathrm{Nov}$ & 2000 & & & Run with anti-VIV ropes \\
\hline Install upper guide horn & $23 \mathrm{Nov}$ & 2300 & & & \\
\hline Drift to Hole C0002G & $23 \mathrm{Nov}$ & 2400 & & & \\
\hline Drift to Hole C0002G & $24 \mathrm{Nov}$ & 2400 & & & Drifting for $24 \mathrm{~h}$ \\
\hline Drift to Hole C0002G & $25 \mathrm{Nov}$ & 0215 & & & No VIV observed \\
\hline RIH to 1956 m DRF, prepare to reenter hole & $25 \mathrm{Nov}$ & 0300 & & & \\
\hline RIH to $2853 \mathrm{~m}$ DRF & $25 \mathrm{Nov}$ & 0530 & & & \\
\hline Hook up cementing line & $25 \mathrm{Nov}$ & 0600 & & & \\
\hline $\begin{array}{l}\text { Land } 18-3 / 4 \text { inch and 9-5/8 inch casing hanger on } \\
\text { wellhead }\end{array}$ & $25 \mathrm{Nov}$ & 0615 & & & \\
\hline Cement $9-5 / 8$ inch casing & $25 \mathrm{Nov}$ & 0930 & & & \\
\hline Release casing hanger running tool & $25 \mathrm{Nov}$ & 0945 & & & \\
\hline $\mathrm{POOH}$ to $1918 \mathrm{~m} \mathrm{DRF}$ & $25 \mathrm{Nov}$ & 1215 & & & \\
\hline Move rig to $50 \mathrm{~m}$ offset & $25 \mathrm{Nov}$ & 1230 & & & \\
\hline Drop sponge ball and circulate & $25 \mathrm{Nov}$ & 1245 & & & \\
\hline Recover ROV on deck & $25 \mathrm{Nov}$ & 1330 & & & \\
\hline Rig down upper guide horn & $25 \mathrm{Nov}$ & 1530 & & & \\
\hline $\mathrm{POOH}$ to $1795 \mathrm{~m} \mathrm{DRF}$ & $25 \mathrm{Nov}$ & 1600 & & & \\
\hline $\mathrm{POOH}$ to $1360 \mathrm{~m} \mathrm{DRF}$, removing ropes & $25 \mathrm{Nov}$ & 2045 & & & \\
\hline Continue $\mathrm{POOH}$ to $265 \mathrm{~m} \mathrm{DRF}$ & $25 \mathrm{Nov}$ & 2400 & & & \\
\hline Continue $\mathrm{POOH}$ to surface & $26 \mathrm{Nov}$ & 0045 & & & \\
\hline Pick up cement stand and inspect cement head & $26 \mathrm{Nov}$ & 0200 & & & Observe wiper plug stuck above drop indicator \\
\hline Move to Shimizu Port & $26 \mathrm{Nov}$ & 0200 & & & \\
\hline Standby $7 \mathrm{nmi}$ off Shimizu Port & $27 \mathrm{Nov}$ & 0030 & & & \\
\hline Port call & $27 \mathrm{Nov}$ & 0700 & & & \\
\hline Leave Shimizu Port & $27 \mathrm{Nov}$ & 2000 & & & \\
\hline Move to $7 \mathrm{nmi}$ upstream of Hole $\mathrm{C} 0002 \mathrm{G}$ & $28 \mathrm{Nov}$ & 1730 & & & \\
\hline Stop vessel set DP mode, install ROV cursor & $28 \mathrm{Nov}$ & 2030 & & & \\
\hline Run drill-out cement assembly to $1143 \mathrm{~m} \mathrm{DRF}$ & $28 \mathrm{Nov}$ & 2030 & & & \\
\hline Continue to RIH drill-out assembly to $1860 \mathrm{~m} \mathrm{DRF}$ & $29 \mathrm{Nov}$ & 0130 & & & \\
\hline Dive ROV & $29 \mathrm{Nov}$ & 0315 & & & \\
\hline Drift to Hole C0002G & $29 \mathrm{Nov}$ & 0430 & & & \\
\hline RIH to 2826 m DRF & $29 \mathrm{Nov}$ & 0730 & & & \\
\hline Drill out cement & 29 Nov & 0830 & & & $\begin{array}{l}\text { Ream around float shoe three times. Float shoe bottom } \\
2853 \text { m DRF }\end{array}$ \\
\hline Wash down to $2937 \mathrm{~m}$ DRF & 29 Nov & 0930 & & & \\
\hline $\begin{array}{l}\text { Sweep } 10 \mathrm{~kL} \mathrm{Hi} \text {-Vis mud pill and spot } 15 \mathrm{~kL} \text { of } \mathrm{Hi}-\mathrm{Vis} \\
\text { mud pill on bottom }\end{array}$ & $29 \mathrm{Nov}$ & 1030 & & & \\
\hline Short trip to $9-5 / 8$ inch float shoe & $29 \mathrm{Nov}$ & 1100 & & & \\
\hline RIH to 2943 m DRF & $29 \mathrm{Nov}$ & 1215 & & & \\
\hline Pump $90 \mathrm{spm}$ and sweep out with $10 \mathrm{~m}^{3} \mathrm{Hi}$-Vis mud & $29 \mathrm{Nov}$ & 1315 & & & \\
\hline Pick up to $2930 \mathrm{~m}$ DRF. Spot $\mathrm{NaCl}$ and protect zone & $29 \mathrm{Nov}$ & 1530 & & & \\
\hline $\begin{array}{l}\text { Drop Churchill drift gauge at } 2930 \text { m DRF and } \\
\text { POOH to wellhead }\end{array}$ & $29 \mathrm{Nov}$ & 1715 & & & \\
\hline $\mathrm{POOH}$ to surface with drifting & $29 \mathrm{Nov}$ & 2200 & & & \\
\hline Move vessel $20 \mathrm{nmi}$ northwest from Hole C0002G & $29 \mathrm{Nov}$ & 2400 & & & \\
\hline $\begin{array}{l}\text { Pick up CORK running tool and make up with pup } \\
\text { joint and XO }\end{array}$ & $30 \mathrm{Nov}$ & 0500 & & & \\
\hline
\end{tabular}


Table T1 (continued). (Continued on next page.)

\begin{tabular}{|c|c|c|c|c|c|}
\hline \multirow[b]{3}{*}{ Operation } & \multicolumn{2}{|c|}{ Start } & \multirow{2}{*}{\multicolumn{2}{|c|}{ Depth DSF $(m)$}} & \multirow[b]{3}{*}{ Comments } \\
\hline & \multirow{2}{*}{$\begin{array}{l}\text { Date } \\
(2010)\end{array}$} & \multirow{2}{*}{$\begin{array}{l}\text { Local time } \\
\quad(h)\end{array}$} & & & \\
\hline & & & Top & Bottom & \\
\hline Install two wiper plugs and rack cement stand & $30 \mathrm{Nov}$ & 0645 & & & \\
\hline Rig down upper guide horn & $30 \mathrm{Nov}$ & 0730 & & & \\
\hline Prepare for running completion assembly & $30 \mathrm{Nov}$ & 1000 & & & \\
\hline Run completion assembly & $30 \mathrm{Nov}$ & 2300 & & & \\
\hline Continue to run completion assembly & $1 \mathrm{Dec}$ & 0000 & & & Run completion assembly to $49 \mathrm{~m}$ DRF \\
\hline $\begin{array}{l}\text { Connect and terminate } 3 \text { cables, flatpack, and } \\
\text { thermistor string }\end{array}$ & $1 \mathrm{Dec}$ & 0700 & & & \\
\hline $\begin{array}{l}\text { Run } 2 \text { joints of } 3.5 \text { inch tubing, attaching } 4 \\
\text { centralizers per joint }\end{array}$ & $1 \mathrm{Dec}$ & 2145 & & & \\
\hline Run completion assembly from 90 to $206 \mathrm{~m}$ DRF & $2 \mathrm{Dec}$ & 0000 & & & \\
\hline $\begin{array}{l}\text { Pick up and make up swellable packer joint and } 2 \\
\text { joints tubing }\end{array}$ & $2 \mathrm{Dec}$ & 1400 & & & \\
\hline $\begin{array}{l}\text { Install } 3 \text { electric cables and flatpack into swellable } \\
\text { packer }\end{array}$ & $2 \mathrm{Dec}$ & 1630 & & & \\
\hline Test 3 cables after installation into packer & $2 \mathrm{Dec}$ & 2215 & & & \\
\hline $\begin{array}{l}\text { Resume running completion assembly from } 220 \text { to } \\
227 \mathrm{~m} \mathrm{DRF}\end{array}$ & $2 \mathrm{Dec}$ & 2300 & & & \\
\hline Continue to run completion assembly to $335 \mathrm{~m}$ DRF & $3 \mathrm{Dec}$ & 0000 & & & \\
\hline Troubleshoot on hydraulic unit of working cart & 3 Dec & 0500 & & & \\
\hline Run completion assembly from 335 to $948 \mathrm{~m}$ DRF & $3 \mathrm{Dec}$ & 0830 & & & \\
\hline $\begin{array}{l}\text { Take off quick lifting tool and prepare for CORK pick- } \\
\text { up }\end{array}$ & $4 \mathrm{Dec}$ & 0000 & & & \\
\hline Pick up CORK running tool and engage on CORK & $4 \mathrm{Dec}$ & 0045 & & & \\
\hline Make up CORK on 3.5 inch tubing & $4 \mathrm{Dec}$ & 0145 & & & \\
\hline Lower CORK to moonpool & $4 \mathrm{Dec}$ & 0200 & & & \\
\hline Test 3 cables prior to termination & $4 \mathrm{Dec}$ & 0400 & & & \\
\hline Mark and measure 3 control lines and terminate & $4 \mathrm{Dec}$ & 0500 & & & \\
\hline Wind all cables and flatpack to winches & $4 \mathrm{Dec}$ & 0645 & & & \\
\hline Terminate electrical cables on CORK & $4 \mathrm{Dec}$ & 0730 & & & \\
\hline Continue termination on cables & $5 \mathrm{Dec}$ & 0000 & & & \\
\hline Connect 3 hydraulic lines on CORK & $5 \mathrm{Dec}$ & 0600 & & & \\
\hline Install 3 ODI connectors and cables to CORK & $5 \mathrm{Dec}$ & 0830 & & & \\
\hline Prepare to install ROV platform & $5 \mathrm{Dec}$ & 1400 & & & \\
\hline Drift $22 \mathrm{nmi}$ to Hole $\mathrm{C} 0002 \mathrm{G}$ & $5 \mathrm{Dec}$ & 1530 & & & \\
\hline Install ROV platform & $5 \mathrm{Dec}$ & 1645 & & & \\
\hline Run 1 stand of DP to $1010 \mathrm{~m} \mathrm{DRF}$ & $5 \mathrm{Dec}$ & 1945 & & & \\
\hline RIH to $1010 \mathrm{~m}$ DRF, install Accelerometer 1 & $5 \mathrm{Dec}$ & 2030 & & & \\
\hline RIH to 1300 m DRF, dive ROV & $5 \mathrm{Dec}$ & 2230 & & & \\
\hline Attach 4 ropes on drill string, recover ROV & $5 \mathrm{Dec}$ & 2245 & & & \\
\hline RIH completion assembly $1300-1417$ m DRF & $6 \mathrm{Dec}$ & 0000 & & & \\
\hline Engage ODI connectors and test 3 cables with ROV & $6 \mathrm{Dec}$ & 0200 & & & \\
\hline Resume RIH from 1417 to $1800 \mathrm{~m} \mathrm{DRF}$ & $6 \mathrm{Dec}$ & 0430 & & & \\
\hline Continue drifting to Hole $\mathrm{C} 0002 \mathrm{G}$ & $6 \mathrm{Dec}$ & 0830 & & & \\
\hline Continue drifting to Hole $\mathrm{C} 0002 \mathrm{G}$ & $7 \mathrm{Dec}$ & 0000 & & & \\
\hline Continue drifting to Hole $\mathrm{C} 0002 \mathrm{G}$ & $8 \mathrm{Dec}$ & 0000 & & & \\
\hline Run completion string from 1800 to $1897 \mathrm{~m}$ DRF & $8 \mathrm{Dec}$ & 0045 & & & \\
\hline Continue drifting to Hole $\mathrm{C} 0002 \mathrm{C}$ & $8 \mathrm{Dec}$ & 0200 & & & \\
\hline Test 3 cables by ROV & $8 \mathrm{Dec}$ & 0430 & & & \\
\hline Check completion assembly condition & $8 \mathrm{Dec}$ & 0515 & & & \\
\hline Resume RIH to $1963 \mathrm{~m} \mathrm{DRF}$ & $8 \mathrm{Dec}$ & 0615 & & & \\
\hline Adjust vessel position and reenter wellhead & 8 Dec & 0845 & & & \\
\hline Resume RIH to 2904 m DRF & $8 \mathrm{Dec}$ & 0915 & & & \\
\hline Pick up and make up cement stand connect to HPS & $8 \mathrm{Dec}$ & 1945 & & & \\
\hline Land CORK head on wellhead & $8 \mathrm{Dec}$ & 2015 & & & \\
\hline $\begin{array}{l}\text { Connect ODI connector and test tiltmeter and } \\
\text { strainmeter }\end{array}$ & $8 \mathrm{Dec}$ & 2015 & & & \\
\hline Pump $64 \mathrm{~m}^{3}$ of seawater & 8 Dec & 2215 & & & \\
\hline Continue to mix cement slurry, total $44 \mathrm{bbl}$ & $9 \mathrm{Dec}$ & 0045 & & & \\
\hline Complete cementing & 9 Dec & 0230 & & & \\
\hline Set unjay stopper and release CORK running tool & $9 \mathrm{Dec}$ & 0330 & & & \\
\hline Rack back cement stand, move vessel $30 \mathrm{nmi}$ south & $9 \mathrm{Dec}$ & 0415 & & & \\
\hline Drop sponge ball and circulation & $9 \mathrm{Dec}$ & 0430 & & & \\
\hline POOH CORK running tool to $1720 \mathrm{~m} \mathrm{DRF}$ & 9 Dec & 0500 & & & \\
\hline Recover ROV on deck & 9 Dec & 0750 & & & \\
\hline Recover CORK running tool on surface & $9 \mathrm{Dec}$ & 1355 & & & \\
\hline Dive ROV for pressure unit testing & $9 \mathrm{Dec}$ & 1825 & & & \\
\hline Test pressure unit & $9 \mathrm{Dec}$ & 1910 & & & \\
\hline Recover ROV on deck & 9 Dec & 0750 & & & \\
\hline
\end{tabular}


Table T1 (continued).

\begin{tabular}{|c|c|c|c|c|}
\hline \multirow[b]{3}{*}{ Operation } & \multicolumn{2}{|c|}{ Start } & \multirow{2}{*}{ Depth DSF $(m)$} & \multirow[b]{3}{*}{ Comments } \\
\hline & \multirow{2}{*}{$\begin{array}{l}\text { Date } \\
(2010)\end{array}$} & \multirow{2}{*}{$\begin{array}{l}\text { Local time } \\
\text { (h) }\end{array}$} & & \\
\hline & & & Bottom & \\
\hline Dive ROV to recover transponders & 9 Dec & 1825 & & \\
\hline Recover ROV on deck & 9 Dec & 2030 & & \\
\hline
\end{tabular}

$\mathrm{DRF}=$ drilling depth below rig floor, $\mathrm{mbsl}=$ meters below sea level, $\mathrm{mbsf}=$ meters below seafloor, $\mathrm{DSF}=$ drilling depth below seafloor. TD = total depth. $\mathrm{RIH}=$ run in hole, $\mathrm{POOH}=$ pull out of hole. $\mathrm{LCA}=$ low-current area. $\mathrm{VIV}=$ vortex-induced vibration. ROV = remotely operated vehicle. $\mathrm{LWD}=$ logging while drilling, $\mathrm{MWD}=$ measurement while drilling. $\mathrm{BHA}=$ bottom-hole assembly. $\mathrm{DP}=$ dynamic positioning. $\mathrm{XO}=\mathrm{crossover}$. ODI = Ocean Design, Inc. bbl = 42 gallon barrel. CORK = circulation obviation retrofit kit.

Table T2. Depth of major observatory items along with the unit boundary, Hole C0002G.

\begin{tabular}{lrrr}
\hline & $\begin{array}{c}\text { Depth } \\
\text { DRF }(\mathrm{m})\end{array}$ & $\begin{array}{r}\text { Depth } \\
(\mathrm{mbsf})\end{array}$ & \multicolumn{1}{c}{ Remarks } \\
\hline ROV platform & & & $\begin{array}{c}\text { Pressure recorder valves and three } \\
\text { underwater mateable connectors }\end{array}$ \\
& & & \\
Seafloor & 1966.00 & 0.00 & \\
20 inch casing shoe & 2006.90 & 40.90 & \\
Swellable packer & 2706.79 & 750.79 & \\
Top of screened casing & 2725.97 & & \\
$\quad$ Pressure Port PP3 & & & \\
$\quad$ Thermistor String T5 & & & \\
$\quad$ Thermistor String T4 & & & \\
Bottom of screened casing & 2744.57 & & \\
$\quad$ Thermistor String T3 & & & \\
Float collar (target of top of cement) & 2785.87 & 819.87 & \\
$\quad$ Thermistor String T2 & & & \\
9-5/8 inch casing shoe & 2853.80 & 887.80 & \\
12-1/4 inch hole TD & 2858.00 & 892.00 & \\
Instrument carrier & 2867.68 & 901.68 & \\
$\quad$ Geophone/Accelerometer & & & \\
$\quad$ LILY tiltmeter & & & \\
$\quad$ Guralp CMG3T & & & \\
Strainmeter sensing & & & \\
$\quad$ Pressure Port PP2 & & & \\
$\quad$ Cement port & & & \\
$\quad$ Pressure Port PP1 & & & \\
Bullnose (end of completion string) & 2915.11 & 949.11 & \\
10-5/8 inch TD & 2946.00 & 980.00 & \\
\hline
\end{tabular}

ROV = remotely operated vehicle. TD = total depth. 
Table T3. Instrument function checklist, Site C0002.

\begin{tabular}{ll}
\hline \multicolumn{1}{c}{ Instrument } & \multicolumn{1}{c}{ Check point } \\
\hline Guralp CMG3T & Consumed current \\
& Tilt readings \\
& Binary data received? \\
& Command control performed? \\
Tilt combo & Consumed current (when tiltmeter, accelerometer, and thermometer array running) \\
& Binary data received? \\
& Command controllable? \\
& Clock synchronization \\
& Accelerometer readings ( $x, y$, and $z$ component in $\left.m / s^{2}\right)$ \\
& Tiltmeter readings $(x, y$, temperature, and magnetometer reading) \\
& Thermometer array reading (check temperature value) \\
& Geophones are locked? \\
Internal battery voltage and disconnected status \\
Strainmeter & Consumed current \\
& Binary data received? \\
& Command controllable? \\
& Clock synchronization \\
& Pressure and temperature reading (check value) \\
& Valve status for protection during installation \\
& Operate valve and strain transducer and pressure respond to valve motion appropriately \\
& Internal battery voltage and disconnected status \\
&
\end{tabular}

Table T4. Borehole temperature data obtained when the completion string landed on the borehole, Site C0002.

\begin{tabular}{lll}
\hline $\begin{array}{c}\text { Depth } \\
\text { (mbsf) }\end{array}$ & $\begin{array}{c}\text { Temperature } \\
\left({ }^{\circ} \mathrm{C}\right)\end{array}$ & \multicolumn{1}{c}{ Location } \\
\hline 761.5 & 29.37 & T1 (thermometer array) \\
767.5 & 29.56 & T2 \\
799.5 & 30.33 & T3 \\
864.5 & 32.97 & T4 \\
899.5 & 34.34 & T5 \\
& 34.25 & Tilt logger pressure housing \\
& 33.99 & LILY tiltmeter housing \\
& 31.28 & Strainmeter pressure housing \\
\hline
\end{tabular}

